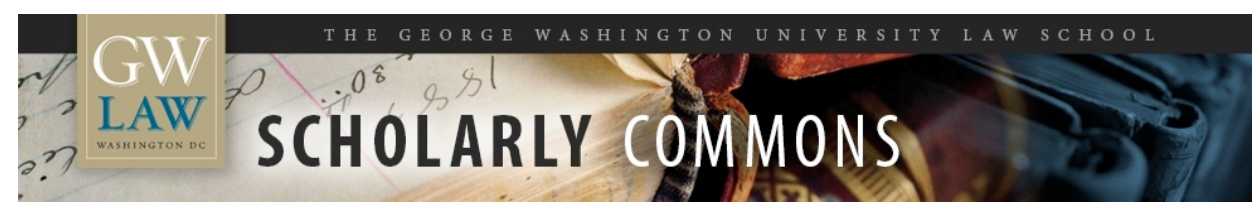

GW Law Faculty Publications \& Other Works

Faculty Scholarship

2012

\title{
Using Law and Equity for Poor and the Environment
}

Dinah L. Shelton

George Washington University Law School, dshelton@law.gwu.edu

Follow this and additional works at: https://scholarship.law.gwu.edu/faculty_publications

Part of the Law Commons

\section{Recommended Citation}

Dinah Shelton, Using law and equity for poor and the environment, in POVERTY ALLEVIATION AND

ENVIRONMENTAL LAW 11-52 (Yves Le Bouthillier et al. eds., 2012).

This Article is brought to you for free and open access by the Faculty Scholarship at Scholarly Commons. It has been accepted for inclusion in GW Law Faculty Publications \& Other Works by an authorized administrator of Scholarly Commons. For more information, please contact spagel@law.gwu.edu. 


\section{Poverty Alleviation and Environmental Law}

Edited by

Yves Le Bouthillier

Professor of Law, University of Ottawa, Canada

Miriam Alfie Cohen

Professor-Researcher, Universidad Autónoma Metropolitana, Cuajimalpa, Mexico

Jose Juan Gonzalez Marquez

Professor of Law, Universidad Autónoma Metropolitana, Azcapotzalco, Mexico

Albert Mumma

Projessor of Law, University of Nairobi, Kenya

Susan Smith

Professor of Law, Willamette University, USA

THE IUCN ACADEMY OF ENVIRONMENTAL LAW SERIES

\section{Edward Elgar}

Cheltenham, UK • Northampton, MA, USA 


\section{Using law and equity for the poor and the environment}

\section{Dinah Shelton}

In October 1991, the periodic shift of wind direction that Californians experience, usually in the autumn, arrived around the San Francisco Bay. The normal off-shore coastal breeze disappeared and the so-called 'Santa Ana' winds blew in from the desert, coinciding with unusually hot and dry days. The winds were much stronger than normal and they picked up embers from a construction site high in the East Bay hills, creating a conflagration known as the 'Oakland Firestorm'. The fire destroyed nearly 4000 homes and killed 28 people in the space of a day. Some of the displaced persons were given refuge temporarily in the Claremont Resort Hotel, where each one was registered as a 'Distressed Person'. Most of the fire victims were insured and the insurance companies had agents available within 24 hours, providing funds to meet initial expenses. The insurance policies largely covered the costs of rebuilding and refurnishing a destroyed home; they also covered the cost of renting a comparable residence until the rebuilding project was completed. In the meantime, local, state and federal officials provided assistance to those burned out of their homes. Shops gave discounts for the purchase of replacement goods. Other communities reached out to help. The neighborhood rebuilt itself completely within a couple of years and became a highly-desirable area in which to live. Only the elderly did not return, because the stress of the fire took their lives within months.

In New Orleans, the Lower Ninth Ward is not elevated. It is in the flatlands and like most such areas, its residents are poor; over 98 per cent of them are African-American. When Hurricane Katrina threatened in 2005, most of those living in the wealthier parts of the city were able to leave before the storm made landfall. Those in the Ninth Ward could not. Of the nearly 2000 people killed during Katrina, 70 per cent of them were black and poor; most of them came from the Ninth Ward. Those who could escape their houses had no resort hotel to house them; instead, thousands of them were herded into a football arena, the Super Dome, where they were kept with little food or water, and where the sanitation facilities were overwhelmed after the first day. The aftermath further exacerbated the disproportionate 
impact of Katrina on the poor, as the latter were wholly underserved by the government and private relief agencies, creating a second disaster. The residents of the Ninth Ward had no insurance to cover immediate expenses or long-term rebuilding, because they could not afford it; they had no funds with which to obtain alternative shelter. The federal government eventually provided some temporary housing, in mobile homes later revealed to be contaminated with toxic chemicals, contamination known to the manufacturer and the government at the time they made available the mobile homes. Eventually some of the residents of the Ninth Ward were relocated as far away as Texas and Colorado, never to return to their former homes. Nearly five years later, the community, has not been rebuilt; much of it looks the same as it did shortly after the hurricane. New Orleans as a whole is whiter, older and richer.

Desmond Tutu has accurately described the global version of this tale of two cities as 'adaptation apartheid' (UNDP, 2007, p. 13). It is not limited to the consequences and impacts of abrupt natural disasters, but can also be observed in measures being taken to adapt to more long-term anthropogenic climate change. In some wealthy countries, adaptation means ski resort operators are buying artificial snow machines; along coastlines, residents are constructing luxurious floating homes. In poor countries, the women and children in coastal areas are being taught to float and to sivim, so they can survive storm surges and flooding.

This chapter examines legal concepts and strategies to overcome adaptation apartheid and to make environmental protection and poverty alleviation equally and mutually-reinforcing international priorities. The aim is to ensure that neither environmental protection nor poverty alleviation is viewed simply as instrumental to achieving the other goal. While conditions of poverty are among the factors contributing to environmental degradation, poverty must be addressed not for that reason alone, but because every human being has an equal right to a life of dignity, with an adequate standard of living, health and well-being. Alleviating poverty is not about charity, but it is about justice and rights, for which there must be'an effective legal framework empowering those in need.

Similarly, while recognizing that a healthier environment can help improve the lives of the poor, environmental protection is its own goal, nature has intrinsic value and the global resource base and ecological services should be conserved for this reason alone. Putting the two goals together is not only possible, it is essential and leads directly to legal approaches based not only on environmental protection, but on environmental justice and human rights. 


\subsection{LINKS BETWEEN POVERTY AND ENVIRONMENTAL HARM}

The World Bank recently raised its benchmark for extreme poverty from $\$ 1$ a day to $\$ 1.25$, but still had to announce on 27 August 2008 that more people are living in that condition than ever before. ${ }^{1}$ Over 1.4 billion people - a quarter of the developing world - are living on less than this amount in the 20 poorest countries, where human development indicators declined significantly over the past decade. ${ }^{2}$ Globally, one in five girls of primary school age is not in school; more than 55 million girls receive no formal schooling whatsoever; in the least developed countries, women are 30 per cent less likely to be literate than men (OHCHR, 2008, p. 25). Those living in such poverty suffer loss of life and health as a direct consequence of the environmental degradation that surrounds their communities. While wealthy families are able to choose where they live and thus largely isolate themselves from pollution and contamination, poor people, especially the oldest and youngest, are less able to escape exposure to pollutants, with disastrous effects on their well-being. NIMBY ('not in my back yard') is a principle that can be successfully invoked almost exclusively by the wealthy and powerful.

Overall, '[a] fifth of the disease burden in developing countries can be linked to environmental risk factors' (OHCHR, 2008, p. 37). The burden of such diseases falls especially hard on the poor who often lack the resources to seek medical treatment. Although some four million infants die in their first month of life and another nearly seven million before they reach the age of five, an estimated 60 per cent of these deaths is preventable (OHCHR, 2008, p. 27). In tropical developing countries, endemic diseases are spread through the poorest communities by ecological disruptions stemming from irrigation projects, dams, construction sites, standing water and poor drainage. ${ }^{3}$ The same connection between ecological damage and other vector-borne diseases has been observed across a range of developing countries (Platt, 1996).

Even in rich countries, like the United States, mortality rates from respiratory illnesses due to pollution are higher among minorities, who make up the ranks of the poor, than they are among whites. Rates of lead poisoning are two to three times higher among poor African-American children than among wealthier white children (Ballard, 1993, pp. 320-325). Extreme local weather events, like the 1996 Chicago heatwave, also have a disproportionate impact on poor minority communities (Sze, 2005, p. 114, n. 4). The impacts are especially felt by the most vulnerable: children born during a drought are 50-79 per cent more likely to be malnourished (UNDP, 2007, p. 9).

It should not be surprising, therefore, to learn that anthropogenic climate change (IPCC, 2001) is predicted to have its most devastating impacts on poor 
and minority communities. The April 2007 IPCC report on climate change impacts, adaptation and vulnerability confirmed that 'the poorest of the poor in the world - and this includes poor people in prosperous societics - are going to be the worst hit'. 4 They already are. The Red Cross estimates that 1998 was the first year in which the number of refugees from environmental disasters exceeded those displaced as a result of war (ICRC, 1999). Between 2000 and 2004, some 262 million people were affected by climate disasters and 98 per cent of them were in the developing world. In OECD countries, 1 in 1500 persons was affected; in developing countries the figure was 79 times higher - one person out of every 19. (UNDP, 2007, p. 8).

Climate change is already having devastating impact on the lives and wellbeing of inland pastoral nomads of Kenya, whose lands and herds have been decimated by persistent drought. In the North the impacts being felt by the Inuits in the Arctic were documented by villagers in the amicus curiae legal brief they filed in the US Supreme Court case Massachusetts v. EPA. ${ }^{5}$ They observed that their very existence is threatened by climate-related disruptions of soils, water, vegetation, and wildlife. Subsistence communities dependent on the ecosystem are hunting at their peril due to thinning ice. There is no practicable alternative food supply and even if alternative sources existed, the loss of traditional foods and the means of acquiring them bring with it a loss of culture and religion. Arctic storms are growing more fierce and frequent; one village lost 15 meters of land overnight in a storm. Afterwards, the residents voted to leave the community they and their ancestors had inhabited for the past 4000 years.

The links between poverty and environmental conditions become more obvious when one considers that poverty is not merely about income or wealth, but encompasses the capability of an individual or group to access the various elements that contribute to ivell-being. ${ }^{6}$ These elements are very closely linked with ecosystem services such as sufficient clean water for drinking and bathing. Persons with money can buy clean water or the equipment to filter and purify water if it is contaminated. The poor have limited resources to pursue these options and usually have to depend on natural and/or public water supply systems. The result is that more than one billion persons lack access to safe drinking water.

The issue, however, is not only, or even primarily one of access to resources. The World Bank's Voices of the Poor found that the poor define poverty as disempowerment and exclusion. ${ }^{7}$ For them, development is about human choice and freedom, the self-determination to decide on a future that is not constrained by sickness, hunger, illiteracy, or oppression. It is about allowing each person to lead the life that he or she values. The emphasis thus has to be on empowering the poor, secing them as rights-bearing agents of change rather than victims requiring aid. 
The eight Millennium Development Goals (MDGs) ${ }^{8}$ which emerged from long discussions about poverty, development and the environment, take a different approach, setting discrete, time-bound and measurable poverty reduction goals. The MDGs view environmental protection as an instrument of poverty alleviation, rather than as a goal in and of itself. They fail to give sufficient attention to arresting and reversing the erosion of natural resources as an independent and valuable aim (World Bank, 2002). In addition to having narrow substantive focus, the MDGs lack mechanisms of accountability, public participation, access to information, and discussion of transboundary obligations in the field of economic, social and cultural rights. They are weak on empowerment, being state-centric and top-down in their approach.

In contrast, the constructs of environmental justice and human rights law provide support to development practices that help realize poverty alleviation through empowering the vulnerable and marginalized in society while ensuring an equitable allocation of resources. Poverty is a legitimate human rights issue, because the poor lack basic social goods, such as health, freedom from violence and intimidation, cultural and spiritual guarantees, and the ability to participate in the political process. Human rights law also has the advantage of offering accountability mechanisms to monitor compliance with the obligations that correspond to the rights bearers and their rights.

\subsection{THE MEANING AND CONTRIBUTION OF ENVIRONMENTAL JUSTICE}

The ethics and morality of any society can be measured partly on the basis of how it treats its most vulnerable members. By this measure, modern society is failing by placing its heaviest environmental burden on those who have been least responsible for creating environmental harm, including climate change, and on those who have the fewest resources to combat or adapt to environmental degradation. More specifically, the poorest 2.6 billion people on earth are being forced to confront climate change which they did not create and over which they have no control, in countries where they have little or no political voice. These facts raise issues of international and domestic environmental justice.

The term environmental justice can be used in many different senses. It may signify a fundamental moral source or rationale providing the underpinnings from which law emerges. Alternatively, it may refer not to a source of law, but to the ultimate goal or outcome to be achieved by legal norms. Environmental justice can also be considered to mean fairness or equity, or more narrowly it can refer to legal institutions and procedures for accountability and dispute settlement. 
To some extent, the different meanings of environmental justice correspond to classic distinctions between procedural, reparative (or corrective) and distributive justice. Consolidating them all, environmental justice can be said to describe a system of norms, institutions and procedures aimed at maximizing the well-being of present and future life on the planet. The primary modalities for achieving this goal include allocation and management of scarce resources, restraints on the exercise of power, and enforcement of the rule of law, aiming to achieve inter-generational, intra-generational and inter-species equity.

Legal scholars for years have equated notions of justice with principles of natural law, the moral foundation of law (Philimore, 1871, p. 20 et seq.). National courts have referred to positive law as deriving from and conforming to "larger considerations of the public good, of commercial liberality, and of international justice ... ${ }^{9}$ In the first decades of the twenticth century, writers expressed a conviction that all positive law emerges from and is inferior to international morality or natural law precepts of justice (Humphrey, 1945). Environmental justice fits into this construct because it reflects and expresses the fundamental values of contemporary society as it combines concem for the environment with concem for the rights and well-being of the poor and vulnerable.

The notion of justice as a set of moral values which precedes, is superior to, and fills in gaps in the law, finds expression in the well-known Martens Clause and its reference to "the principles of the law of nations, as they result from the usages established among civilized peoples, from the laws of humanity, and the dictates of the public conscience'. ${ }^{10}$ In the aftermath of World War II, the proclamation of jus cogens or peremptory norms also reflects the acceptance of a superstructure or international public order within which law and policy function (Silving, 1961).

Environmental justice may also be equated with equity, in the sense of fairness. Equity can allow for exceptions to an otherwise uniformly applied law, in order to provide individualized justice. In international environmental law, some developing countries have negotiated equitable exemptions from legal norms or for preferential treatment on the grounds that the application of the general legal rules without modification would leave them with a disproportionate environmental burden due to the export of pollution from wealthier countries, while they are unable to share in the benefits derived from the polluting activities, and have the least capacity to respond to the resulting environmental challenges.

Equity may also provide a basis for decision in the absence of law or when it is necessary to fill in gaps in existing norms, such as when new issues emerge that give rise to disputes. International tribunals have applied equity in this way, but usually on the basis that the equitable principle being invoked is a general principle of law." 
Positive law itself may designate equity as the basis for allocating rights and duties. ${ }^{12}$ Equity is most often chosen as the rule of decision when the different circumstances or situations of subjects of the law necessitate differential treatment in order to achieve a just result (Akehurst, 1976). Equity has been utilized this way in international environmental law in an effort to fairly allocate and regulate scarce resources in order to ensure that the benefits of environmental resources, the costs associated with protecting them, and any degradation that occurs (that is, all the benefits and burdens) are fairly' shared by all members of society.

Distributive justice represents an ethical imperative based on the notion of moral reciprocity, in which all human beings are treated as equals. Modern law and policy is based on recognition of 'the inherent dignity and of the equal and inalienable rights of all members of the human family [as] the foundation of freedom, justice and peace in the world'. ${ }^{13}$ Since all human beings are born free and equal in dignity and rights, values and policies should be legitimized through individual consent, equal rights, and democratic procedures rather than through utilitarian philosophies based on abstract notions of welfare or economic efficiency. Nonetheless, given the social dimension of all human lives, justice 'cannot be related to any one value, be it equality or any other, but only to the complex value system of a man, a community, or mankind'. ${ }^{14}$

Distributive justice begins with equality but acknowledges that imposing equal obligations on subjects of law that are unequal in relevant ways is likely to exacerbate inequalities or impose unfair burdens on those least able to bear the burdens. Legal systems, including the international legal system, therefore often seek substantive equality in the distribution of societal goods and burdens by treating like alike and unlike differently. Distributive justice of this type is promoted through enactment of specific legal norms that address equitably the consequences of wrongful actions (state responsibility and liability); norms of humane treatment (human rights and humanitarian law); and norms allocating scarce resources.

Relations that have existed between rich and poor countries and rich and poor individuals can be viewed as unjust if they fail to promote equality and to narrow the gap between the haves and have-nots. Moral reciprocity demands redistribution as a matter of justice. Responses to pervasive inequalities in economic development or lack of capacity to tackle a given problem could include imposing differential obligations or providing preferential treatment. Such temporary unequal relationships seek to foster true equality, largely through favoring the least developed or most affected individuals or states. At the national level, this notion led US President William J. Clinton in 1994 to sign an Executive Order on Environmental Justice, which called on each federal agency to identify and address 'disproportionately high and 
adverse human health or environmental effects of its programs, policies, and activities on minority populations and low-income populations' ${ }^{15}$

Distributive justice is inherent in the doctrine of equitable utilization of shared natural resources, taking into account the needs and capabilities of those involved. ${ }^{16}$ The status of equitable utilization as a fundamental and just norm in the field of shared natural resources was affirmed by the ICJ in the Case Concerning the Gabčikovo-Nagymaros Project (Hungary/Slovakia). ${ }^{17}$ In the Fisheries Jurisdiction Cases (UK v. Iceland; FRG v. Iceland), the ICJ stressed the obligation of reasonable use and good faith negotiations aimed at an equitable result, taking into account the needs of conservation and the interests of all exploiters of the resource. ${ }^{18}$

Equitable utilization, as an application of the principle of distributive justice, attempts to reach a fair result based on what are decmed to be relevant factors, such as need, prior use or entitlement, and other interests. Socictal values like environmental protection or human rights may affect the scope and application of equitable principles through insisting on the importance of one or more of the factors. The Watercourses Convention, for example, states that equitable and reasonable uses are to be 'consistent with adequate protection of the ivatercourse'. 9 The phrase implies that uses causing substantial harm to the watercourse might be considered inherently inequitable. It also now appears increasingly accepted that some resource uses have priority over others. In the utilization of freshwater, for example, priority is given to the satisfaction of basic human needs through the provision of safe drinking water and sanitation. ${ }^{20}$ The UN Committee on Economic, Social and Cultural Rights, in its General Comment 12 on the Right to Water, insists that priority be given to safe drinking water and sanitation, with a guarantecd mininum amount to be provided to every person. ${ }^{21}$ Thus, substantive human rights considerations take precedence over other factors in allocation.

Positive lavv supports other mcasures of distributive or corrective justice. At the international level, concern about the equitable distribution of the burdens of environmental protection has led to the creation of a series of financial mechanisms, exemptions, provisions for the transfer of technology, and flexibility in the time required for compliance with international obligations, all part of the concept of common but differentiated responsibilitics (Drumbl, 2002). Capacity building through the provision of financial resources and the transfer of technology is widely included in global multilateral environmental agreements. Treaty provisions that explicitly recognize economic and social development and poverty eradication as the first and overriding priorities of developing country parties generally make the provision of financial resources and the transfer of technology from developed country parties a condition for the implementation of treaty obligations by developing country partics. Thus, Article 5(5) of the amended Montréal Protocol on Substances that Deplete the 
Ozone Layer (Montréal Protocol) provides that developing countries' capacity to fulfil the obligations and implement the control measures specified in the Montréal Protocol will depend upon the effective implementation by developed nations of financial cooperation and transfer of technology as set out in the Protocol. ${ }^{22}$ Similar statements are contained in Article 4(7) of the United Nations Framework Convention on Climate Change (FCCC) ${ }^{23}$ and Article 20(4) of the Convention on Biological Diversity (CBD). ${ }^{24}$

The principle of corrective justice supports the demand that developed nations pay for any reductions or modifications the developing world has to make in the process of industrialization, because developed-world industrialization has unfairly circumscribed the ability of the developing world to pass off the negative externalities of development on the environment. The global community finds itself at the tipping point because of the conduct of the developed world. It is precisely because of this conduct that the marginal environmental costs of developing-nation industrialization today are high. It is thus unfair to allocate each state or each person an equal share of total permissible pollution in the present, given the past high levels of pollution emitted by some countries and persons.

Corrective justice thus substantiates the notion that developing nations and the poor today are entitled to the resources and technology from developed nations. Developed nations should have to internalize the environmental costs of ongoing and future developing-nation industrialization. While the corrective justice model brushes against theories of formal equality of states and individuals, achieving justice in the present requires taking into account elements from the past.

Environmental justice, in sum, means a rational sharing of the burdens and costs of environmental protection, discharged through the procedural and substantive adjustment of rights and duties. While certain stated principles of environmental law seem to aim for such international justice, there has been an evident strong resistance to aiding the 'have-nots' on the part of some of those who 'have', within and across states. To the extent progress has been made in fairly allocating benefits and burdens in international environmental lav, it may be considered the result of ecological interdependence and issue-linkages. Developed countries increasingly recognize that they must have the cooperation of developing states if the global environment is to be restored and maintained; they cannot do it on their own. Benefit and burden-sharing then becomes the just price demanded by the developing world for its cooperation.

Justice and equity, with their emphasis on fairness, are more attractive concepts than economic efficiency or open conflict as a means of deciding how to allocate and sustain limited common resources. Without a cooperative and just solution to the issue of allocation, competitive utilization of the resource may continue until the resource is depleted. Equitable or differentiated 
obligations may induce participation in action among the competing states as well as among states that may not have any direct interest in a specific environmental issue.

Equity also may be justified on the basis of self-interest. An allocation of burdens that takes into account the more vulnerable position of developing states may benefit all through inducing the cooperation of such states to improve global environmental conditions. ${ }^{25}$ Thus, environmental justice is not only a matter of morality and equity but may also foster more effective action on issues of common concern and more effective implementation of legal norms. Equity, as reflecting notions of fairness and legitimacy, may produce more or better compliance with environmental agreements. In practice, therefore, equitable differentiation is the price to be paid to ensure universal participation in measures to tackle global environmental problems. Yet, it should not be forgotten, as Thomas Franck has noted, that ' $\mathrm{t}$ ]he law promotes distributive justice not merely to secure greater compliance, but primarily because most people think it is right to act justly' (Franck, 1995, p. 8).

\subsection{LEGAL CONSTRUCTS TO GIVE EFFECT TO ENVIRONMENTAL JUSTICE}

Principles of environmental justice (distributive, procedural and corrective) provide organizing principles in the efforts to combat poverty and environmental degradation. It remains to be seen how such principles can be integrated into domestic and international laws and policies. There are four legal constructs or approaches which have had some suecess and where further achievements are possible. These are not mutually exclusive approaches; indeed, all of them are necessary and must be pursued. In general, legal measures to combat disproportionate environmental impacts on the poor and address poverty can be grouped into the following broad categories: traditional private law, especially tort and property law; public regulation; market mechanisms; and constitutional or human rights law.

\subsubsection{Private Law}

Private law first incorporated principles of justice, especially corrective justice, in response to claims of environmental harm. Private law concepts can be seen internationally in the inter-state Trail Smelter arbitration. ${ }^{26}$ The arbitral panel, which found no international treaties or precedents on point for transboundary air pollution, relied heavily on inter-state cases from within federal systems. Most of these judgments were, in turn, founded on private law concepts of nuisance. Nuisance is an equitable doctrine that imposes liability 
when, after examining and balancing the benefits and burdens accruing to litigating parties, one party's use of property or resources is found to be an unreasonable or unjust interference with the other party's property or other interests. Private tort actions were long the primary avenue for mitigating or halting pollution. A modern variant can be seen in the application of the polluter pays principle in liability regimes.

Significantly, the recent US Supreme Court judgment in Massachusetts $v$. $E P A^{27}$ relied on Georgia v. Tennessee Copper Company and Ducktown Sulphur, Copper and Iron Company, Ltd., ${ }^{28}$ the same key 1907 case utilized by the Trail Smelter tribunal. It did so in its analysis that found standing for states and local communities to sue the EPA for its failure to regulate greenhouse gases. The judgment and the multitude of briefs filed in the case suggest that the possibility remains open for a variety of actions to combat transfrontier pollution as a form of international nuisance, including from emission of greenhouse gases.

The challenge today is to use concepts like nuisance on behalf of the poor, indigenous, and minorities who are bearing a disproportionate environmental burden without obtaining corresponding benefits. Domestically it means challenging the siting of polluting activities in poor neighbourhoods. Internationally, it requires addressing the export of polluting industries and activities, as well as toxic waste, to poor countries and acknowledging and addressing the impacts of climate change. Applying past doctrines to contemporary problems requires research into the facts and potential causes of action, making use of legal clinics at law schools, pro bono representation, and participation in amicus curiac briefs.

In addition to allowing private actions based in tort, some countries have relied on the long-established property doctrine of public trust to protect those resources deemed to fall within the public domain. The doctrine of public trust, traced to Roman law, holds that navigable waters, the sea, and the land along the seashore are common property open to use by all (Justinian Institutes, translation 1876). Given its long-standing recognition as a legal doctrine, courts may recognize and enforce public trusts without legislation. ${ }^{29}$

The public trust doctrine emphasizes the equal right of access and use of the trust corpus by all in the present and the preservation of the trust for the future. It emphasizes the duties of the government as trustee, imposing on it an obligation to conserve the public trust asset and ensure common access to and use of it by present and future generations. ${ }^{30}$ One limitation is that the public trust doctrine extends only to those natural resources which are viewed as part of the corpus of the trust and not to the environment as a whole. ${ }^{31}$ However, the publication of Joe Sax's influential law review article in 1970, ${ }^{32}$ has led some legislatures, litigants and courts to expand the doctrine and apply it to other resources, including wildlife and public lands. ${ }^{33}$ 
Efforts to invoke the public trust doctrine to protect the environment more broadly face three challenges. The first challenge is to examine comparatively the concept of the public trust to determine the extent to which it has already been applied to protect natural resources. The second challenge is to follow through on the implications of the public trust doctrine. Several subsidiary rules of trust law could be important in fleshing out the application of justice principles, such as those that require the trustee to monitor and report on the status of the trust corpus and those that ensure equal access for all, including the poor. These rules should impose legal obligations on public officials to monitor the state of the environment and provide information periodically to the public in an accessible form and through an accessible medium.

The third challenge is to examine the appropriateness of extending the public trust doctrine to the air, ecological processes, biodiversity and other components of the environment. Some lavs already extend beyond the traditional coastline and fishing : resources. Hawaii's constitution, for example, creates a public trust over all of the state's natural resources:

For the benefit of present and future generations, the State and its political subdivisions shall conserve and protect Hawaii's natural beauty and all natural resources, including land, water, air, minerals and energy sources, and shall promote the development and utilization of these resources in a manner consistent with their conservation and in furherance of the self-sufficiency of the State. All public natural resources are held in trust by the State for the benefit of the people. ${ }^{3+}$

In international law, there are aspects of the doctrine already inherent in the concept of the common heritage of mankind, which recognizes that certain resources, such as those on or under the deep seabed, belong to the common heritage of mankind by virtue of their location in commons areas. Inclusion of the word 'heritage' connotes a temporal aspect in the communal safeguarding of areas or resources incapable of national appropriation. The nature of the common heritage is a form of trust, whose principal aims include restricting use to peaceful purposes, rational utilization in a spirit of conservation, good management or wise use, and transmission to future generations. Benefits derived from the common heritage may be shared through equitable allocation of revenues, or a sharing of scientific knowledge. It would be useful to consider how this might be expanded to the oceans as a whole, to ecosystems like coral reefs, to biodiversity, or the atmosphere.

\subsubsection{Regulation}

In the 1960s environmental law shifted from a reliance on property and tort law to one of public regulation. General environmental protection statutes were enacted along with specific laws to ensure clean watter, clean air, and the 
survival of endangered species. Christopher Schroeder has pointed out that the shift from private to public law has three advantages in theory - 'one procedural, one remedial and one substantive' (Schroeder, 2002). On a procedural level, environmental regulation done right determines levels of environmental quality through a public process that involves collective choices, rather than through a series of private actions and reactions (negotiation or litigation). Of course, this process may be distorted by a lack of transparency or lobbying by powerful interests, but in theory it offers the benefits of a democratic and participatory process, especially if governance is based on theories of subsidiarity or decentralization in which those affected are directly involved in the decision-making.

Secondly, regulation emphasizes prevention rather than liability (although successful nuisance actions often lead to injunctive relief to prevent further harm). Prevention is a more efficient, cost-effective approach and also one that can help avoid irreparable harm. Finally, substantively, the regulatory system sets levels of environmental quality that the cost-benefit or balancing approach used in tort actions cannot normally achieve, because the latter tend to rely on corrective justice rather than deterrence and they may underestimate the collective losses caused by environmental harm (Schroeder, 2002).

There are several current challenges posed with the regulatory model: (1) determining at what level of governance - local, state, regional or international - regulations should be enacted; (2) coordinating the various regulations across governance units to ensure compatibility and synergies; (3) ensuring that the legal measures adopted are scientifically sound and aim at a high level of protection; (4) making sure that the measures are equitable, that the poor and vulnerable are not made worse off, at a minimum. Thought should be given to amending environmental impact assessment procedures to require that the social as well as the natural impacts of proposed activities and measures be assessed.

\subsubsection{Market Mechanisms}

The third construct became popular beginning in the $1980 \mathrm{~s}$, with deregulation and privatization. Market-based approaches to changing human behavior emerged in preference to command-and-control measures (Bosselmann and Richardson, 1999). In part, this move constituted a reaction to dense regulatory networks that were deemed inefficient and a drain on competitiveness and investment (Reitze, 1989). Economic instruments, however, largely remain within the regulatory framework because they require laws and institutions to oversee their operation. Purely market-based approaches such as voluntary agreements tend to be inequitable, ineffective, and unable to truly account for harm to public goods like air, water and other parts of the commons 
(Rehbinder, 1999). They do not, and perhaps cannot, serve to protect long term interests such as future generations.

For those who believe in market mechanisms, the challenges are to study and leam from the efforts of human rights activists who sought to reduce and eventually end corporate complicity in apartheid by buying shares in companies with poor records and mounting shareholder actions at company mectings. Other techniques include naming and shaming, labelling to cncourage consumer awareness and purchasing choices, and challenging deceptive advertising by companies that claim they are green when they are engaged in the worst industry practices.

\subsubsection{Rights-based Approaches}

The fourth paradigm is the rights-based approach to environmental protection and poverty alleviation. In addition to its focus on ensuring the enjoyment of all civil, political, economic, cultural and social rights, it emphasizes the right to a certain quality of environment because that quality is linked to, indeed a prerequisite for, the enjoyment of internationally and domestically guaranteed rights. Rights-based approaches were initially thought to have the defect of being non-justiciable, but courts are increasingly enforcing constitutional and international rights to environmental quality. Many courts have broadened standing to permit legal redress for violations of environmental rights, without requiring individualized injury to health or property, because one major motive for guarantecing environmental rights is to prevent injury from occurring. ${ }^{35}$

Looking at the domestic level and using the US as an example, on the first Earth Day in 1970 the Pennsylvania legislature approved a proposed amendment to the state constitution, intending to "give our natural environment the same kind of constitutional protection that [is] given our political rights' ${ }^{36}$ The proposed amendment was approved overwhelmingly by voters in the state on 18 May $1971^{37}$ and added what is now Article 1, section 27 of the state constitution. It specifies the right of the people 'to clean air, pure water, and to the preservation of the natural, scenic, historic and aesthetic values of the environment'.

Following this example, more than 30 of the 50 states in the United States, ${ }^{38}$ and more than 130 states around the world, have added constitutional provisions that refer to environmental or natural resource protection as a constitutional right or governmental duty. The amendments generally were enacted for two stated purposes. First, they aim to elevate environmental protection as a fundamental value to a constitutional status above the states' legislative and regulatory norms. Second, they seck to expand the doctrine of standing to allow public interest litigation on behalf of the environment. The 
phrasing differs among the provisions, which in turn impacts their justiciability and scope. Where such provisions are being enforced nationally and internationally, a growing caseload is elaborating the content of environmental rights.

The rights-based approach to implementing principles of justice in law emphasizes each individual's right to a certain quality of environment, because environmental quality is linked to the enjoyment of internationally and domestically guaranteed rights that cannot be exercised in a degraded environment. Even when explicit guarantees of environmental rights are lacking, courts are finding it necessary to take into account environmental quality in order to ensure the effective enjoyment of other human rights. For these reasons, numerous national and international tribunals today address and provide redress for at least some environmental harm.

At the international level, most human rights treaties were drafted and adopted before the 1972 Stockholm Conference on the Human Environment and therefore they contain few references to the environment. ${ }^{39}$ Later treatics ${ }^{40}$ and declarations, ${ }^{41}$ especially at the regional level, ${ }^{42}$ do refer to the right to a safe and healthy or sound environment, while environmental agreements have incorporated procedural human rights deemed necessary or advantageous to achieving environmental protection. ${ }^{43}$ The protections afforded increased in scope and number after the adoption of Principle 10 of the Rio Declaration on Environment and Development. ${ }^{44}$

At the global level, the former United Nations Human Rights Commission took several initiatives relating to human rights and the environment, most of which have been maintained by the new Council. The Special Rapporteur on the adverse effects of the illicit movement and dumping of toxic and dangerous products and wastes on the enjoyment of human rights, ${ }^{45}$ has a mandate that includes investigating complaints about illicit waste trade as a violation of the rights to life, good health and a sound environment. ${ }^{46}$ The mandate of the Special Rapporteur on the right to food includes the issue of access to water, ${ }^{47}$ affirmed as the 'right to drinking water supply and sanitation for every woman, man and child'. ${ }^{48}$ The Human Rights Council that replaced the former UN Commission has also taken up the human rights implications of climate change. ${ }^{49}$

One advantage to a rights-based approach is accountability. International human rights treaty bodies have received and decided cases from applicants who allege that environmental conditions affecting them have deteriorated to the point that their internationally-guaranteed human rights have been violated. The three fully operational regional human rights systems have examined the greatest number of the complaints that environmental deterioration has affected guaranteed human rights. The coming into force of the 2004 Revised Arab Charter on Human Rights ${ }^{50}$ and the insertion of human rights 
clauses in the ASEAN Charter in $2007^{51}$ expand regional human rights systems into new geographic areas and offer possibilitics for lawyers to propose action that reflects and reinforces the jurisprudence of the other regions, just as the older systems have learned from each other.

On the merits of the cases, human rights tribunals are increasingly utilizing environmental standards to adjudicate human rights claims related to the environment and to judge whether or not states have complied with their legal obligations. This suggests an integration of environmental law with concem for individuals that reflects and reinforces the principles of environmental justice.

The European Convention for the Protection of Human Rights and Fundamental Freedoms (ECHR ${ }^{52}$ contains neither a right to health nor a right to environment, but cases have been brought for injury due to environmental harm, invoking the right to life (Article 2), the right to information (Article 10), and the right to privacy and family life (Article 8). In responding to these complaints, the European Court has determined that it must have regard to the changing conditions within its Contracting States generally and must respond to evolving convergence as to the standards to be achieved. The European Court maintains this dynamic and evolutive approach because it finds it is "of critical importance that the Convention is interpreted and applied in a manner which renders its rights practical and effective, not theoretical and illusory'.53 Such an approach benefits environmental rights, which might be excluded from consideration using an 'originalist' interpretation, because most human rights agreements were written before environmental law developed and thus environmental conditions were not contemplated by the treaty drafters. ${ }^{54}$

Applying its evolutive approach, the European Court has indicated that the scope of guaranted rights is affected by the 'growing and legitimate concern both in Europe and internationally about offenses against the environment' 55 It thus concluded that governments may adjust the amount of permissible bail that can be demanded and the length of pre-trial detention according to the particular circumstanees of an environmental disaster. ${ }^{56}$ In reaching this conclusion, the Court took into account the 1982 Convention on the Law of the Sea and its provisions on offenses against the marine environment, MARPOL, ${ }^{57}$ and European law on environmental crimes and liability. ${ }^{58}$

In its first major decision ${ }^{59}$ involving environmental harm as a breach of Article $8 \mathrm{ECHR}$, the European Court held that severe environmental pollution may affect individuals' 'well-being' to the extent that it constitutes a violation of Article 8. The pollution need not reach the point of affecting health, if the enjoyment of home, private and family life is reduced ${ }^{60}$ Moreover, the harm may be excused if it results from an authorized activity of economic benefit to the community in general, provided the principle of distributive justice is respected: that is, as long as there is no disproportionate burden borne by any 
particular individual or group (including the poor). The Court applies a three part test: the measure must have a legitimate aim, be lawfully enacted, and be proportional. ${ }^{61}$ States enjoy a margin of appreciation or certain discretion in determining the legitimacy of the aim pursued, but the Court will hold the state to the level of environmental protection it has chosen and nearly always finds a violation if the state fails to enforce its own laws.

The Court further explained its standard in Fadayeva v. Russia, ${ }^{62}$ noting that because 'no right to nature preservation is as such included among the rights and freedoms guaranteed by the Convention', the adverse effects of environmental pollution must attain a certain minimum level if they are to fall within the scope of Article 8 . The requisite effects or interference need not reach the level of proven injury to health; it is enough if there are serious risks posed. In Fadayeva, the applicant succeeded on her claim because she was made more vulnerable to various diseases, even though quantifiable harm to her health was deemed not proved; in addition, the Court found that her quality of life at her home was adversely affected.

In these and other cases, the European Court has given effect to various human rights linked to environmental protection by reference to international environmental principles, standards and norms. In addition, it has emphasized the importance of enforcing national environmental rights provisions. In so doing the Court has given substantive content to environmental rights and corresponding state obligations.

In Oneryildiz ${ }^{2}$ Turkey, ${ }^{63}$ the European Court of Human Rights made reference to several environmental texts, both binding and non-binding in holding the Turkish government responsible for the loss of life and property resulting from a methane explosion at a waste site. The binding texts deemed relevant were the Lugano Convention on Hazardous Activities ${ }^{64}$ and the Strasbourg Convention on Protection of the Environment through Criminal Law. ${ }^{65}$ The European Court used the Lugano Convention to define 'dangerous activity' and 'damage' incurring the liability of public authorities. It noted the duty under the Strasbourg Convention for authorities to establish criminal offenses for loss of life involving the disposal or treatment of hazardous wastes.

The Court also made reference to non-binding Council of Europe texts, including Parliamentary Assembly Resolution 587 (1975) on problems connected with the disposal of urban and industrial waste; ${ }^{66}$ Resolution 1087 (1996) on the consequences of the Chernobyl disaster, ${ }^{67}$ and Recommendation 1225 (1993) on the management, treatment, recycling and marketing of waste. ${ }^{68}$

In Tuskm and Others v. Turkey, ${ }^{69}$ the Court utilized principles enshrined in the Aarhus Convention on Access to Information, Public Participation in Decision-making and Access to Justice in Environmental Matters, ${ }^{70}$ despite the fact that Turkey had not signed the Aarhus Convention. The applicants 
were challenging under Article 8 the decision of Turkish authoritics, taken after appropriate decision-making procedures, to allow development and operation of a gold mine which the applicants alleged would cause environmental damage to the detriment of people in the region. The applicants litigated the matter and won in domestic courts. The Turkish Supreme Administrative Court repeatedly concluded that the operating permit in issue did not serve the public interest and that the safety measures which the company had taken did not suffice to eliminate the risks involved in such an activity.

In reviewing the applicable legal framework, the Court referred to Rio Principle 10 and the Aarhus Convention, as they set forth procedural rights including access to justice. In addition, however, the Court also quoted from a Parliamentary Assembly resolution on environment and human rights ${ }^{71}$ which recommended that member states ensure appropriate protection of life, health, family and private life, physical integrity and private property, taking particular account of the need for environmental protection, and that member states recognize a human right to a healthy, viable and decent environment including the objective obligation for states to protect the environment in national laws, preferably at the constitutional level. Given this recommendation and the domestic constitutional guarantees, the Court found a violation despite the absence of any accidents or incidents with the mine.

Enforcement of environmental rights involves courts in not only determining what environmental quality the law requires, but also in assessing whether or not the government has taken the requisite actions to achieve that quality. Human rights tribunals have made clear that the state may be responsible whether pollution or other environmental harm is directly calused by the state or whether the state's responsibility arises from its failure to regulate properly private-sector activities. ${ }^{72}$ States must not only respect the observance of rights and freedoms but also guarantec their existence and the free exercise of all of them against private as well as state actors. Thus any act or omission by a public authority which impairs guaranteed rights may violate a state's obligations. ${ }^{73}$ This is particularly important in respect to the environment, where most activities causing harm are undertaken by the private sector.

As noted above, the Court requires at a minimum that the state should have complied with its domestic environmental standards. ${ }^{74}$ The issue of compliance with domestic law is particularly important when there is a domestic constitutional right to environmental protection. The European Court will review governmental actions in the light of the domestic law. In Okyay and Others v. Turkey ${ }^{75}$ the applicants had successfully challenged in domestic courts the operations of thermal-power plants in South-iwest Turkey, which they claimed would damage the environment and pose risks for the life and health of the Acgean region's population. They explicitly argued that Article 56 of the Turkish Constitution guaranteed them the right to life in a healthy 
and balanced environment. They did not argue that they had suffered any economic or other loss. The European Court agreed that they had a right under Turkish law to protection against damage to the environment and that their rights under Article 6(1) ECHR had been violated due to the failure of Turkish authorities to comply in practice and within a reasonable time with the domestic court's judgments.

Domestic constitutional laws and provisions are particularly important in cases where the applicants have no independent claim under the ECHR for severe pollution, but instead are seeking nature protection or protection of the environment more generally. In Kyrtatos $v$. Greece, ${ }^{76}$ as in the Okyay case, the applicants' claim involved a constitutional provision protecting the environment. In domestic courts, the applicants and the Greek Society for the Protection of the Environment and Cultural Heritage asserted that the local prefect's decisions to allow development projects and to issue building permits were illegal, because the area concerned was a swamp safeguarded by Article 24 of the Greek Constitution, which protects the environment. The domestic court held that the prefect had violated Article 24 of the Constitution, because the decision put in jeopardy an important natural habitat for various protected species, including birds, fishes and sea-turtles. It followed that the building permits were also unlawful and had to be quashed. The decision was not enforced by the local authorities, who instead issued further building permits. Given the constitutional provision, the European Court found a violation of Article 6(1), because the domestic law gave environmental rights to the applicants and the government had failed to enforce them.

The African Commission also has identified governmental human rights obligations by reference to environmental norms. In SERAC v. Nigeria, the African Commission held that Article 24 'imposes clear obligations upon a government to take reasonable and other measures to prevent pollution and ecological degradation, to promote conservation, and to secure an ecologically sustainable development and use of natural resources'. ${ }^{77}$ Compliance with these obligations includes ordering or permitting independent scientific monitoring of threatened environments, requiring environmental and social impact studies, monitoring hazardous materials and activities, as well as providing information and an opportunity for the public to participate in decisionmaking. ${ }^{78}$ While the Commission did not cite specific environmental agreements, the obligations it mentions are part of international environmental law.

Beyond ensuring that any domestic environmental rights are enforced, the European Court scrutinizes the adequacy of the domestic law, to see if the state has ensured a fair balance between the interests of the community and the rights of those affected. The Court accords each state a wide margin of appreciation in this respect, because national authorities 'are in principle better placed than an international court to assess the requirements' in a particular 
local context and to determine the most appropriate environmental policies and individual measures while taking into account the needs of the local community, ${ }^{79}$ especially in a technical sphere like environmental protection. ${ }^{80}$ The wide margin of appreciation afforded governments means that the Court will only find a violation if there is a 'manifest error of appreciation' by the national authorities in striking a fair balance between the competing interests of the different private actors. ${ }^{81}$ The final evaluation as to whether the justification given by the state is relevant and sufficient remains subject to review by the Cour ${ }^{82}$ but 'only in exceptional circumstances' will the court look beyond the procedures followed to disallow the conclusions reached by domestic authorities on the environmental protection measures to be taken on the projects and activities allowed to proceed. ${ }^{83}$ Even if it finds that the state decided wrongly, the Court will not determine exactly what should have been done to reduce the pollution in a more efficient way. ${ }^{84}$

Another European supervisory body has also found violations of substantive guarantecs due to the failure of the government to legislate to protect the environment. The first and, to date, only European Social Charter complaint to concern environmental conditions, lodged on 4 April 2005, claimed violations of the Charter's right to health provisions ${ }^{85}$ because the state had not adequately prevented negative environmental impacts nor had it developed an appropriate strategy to prevent and respond to the health hazards stemming from lignite mining. The complaint also alleged that there was no legal framework guarantecing security and safety of persons working in lignite mines. The European Committee of Social Rights concluded that the government had violated the Charter ${ }^{86}$ after examining the Greck National Action Plan for greenhouse gas emissions and finding it inadequate in the light of the state's obligations under the Kyoto Protocol and the principle requiring use of the "best available techniques". ${ }^{87}$ While the Committec found that Greck regulations on information and public participation were satisfactory, the evidence showed inadequate enforcement of the relevant legislation.

The imposition of substantive environmental quality standards does not exclude, but rather reinforces procedural rights. Indeed, human rights tribunals have read the procedural rights and corresponding state obligations into substantive human rights guarantes such as the right to life and to privacy and home life. This approach has been important in instances where the guarantees of procedural rights in human rights instruments are not strong, as is the case in the European Convention. In Guerra v. Itcly, ${ }^{88}$ the applicants alleged that the Italian authorities violated Articles 2,8 and 10 ECHR by failing to mitigate the risk of a major accident at a nearby chemical factory and by witlholding information from local residents about the risks and emergency procedures. The 'right to information' claim was dismissed, because the European Convention does not require the collection and dissemination of 
information about the environment, but the European Court effectively incorporated this requirement into the applicant's Article 8 claim as the 'procedural dimension' of the obligation of states to secure effective respect for the applicants' right to family and home life.

On the merits of the Oneryildiz case, the Court explained that Article 2 ECHR, which guarantees the right to life, applies 'in the context of any activity, whether public or not, in which the right to life may be at stake, and a fortiori in the case of industrial activities, which by their very nature are dangerous, such as the operation of waste-collection sites' ${ }^{89}$ According to European environmental standards, waste disposal is a hazardous activity, therefore Article 2 applies. The resulting duty of care depends on several factors: the harmfulness of the phenomena inherent in the activity; the contingency of the risk to the applicant; the status of those involved in creating the risk, and whether or not the conduct was deliberate. The court merged procedural rights into the substantive evaluation, finding that 'particular emphasis' should be placed on the public's right to information concerning the risks to life and the duty to investigate when loss of life occurs. ${ }^{90}$ Assessing the evidence, the Court found that the authorities must have known of the risk and of the need to take preventive measures "particularly as there were specific regulations on the matter'. ${ }^{11}$ As such they had an obligation as well under Article 2 ECHR, "to take such preventive measures as were necessary and sufficient to protect those individuals ....92

Like Oneryildiz, the case of Budluyeva and Others v. Russia, ${ }^{93}$ concerned governmental knowledge of hazards and the failure to act upon that knowledge. The latter case, howcver, involved repeated natural disasters rather than hazards originating in human activities. The standard of care did not differ appreciably on many of the issues. Governmental authorities aware of mudslide hazards in a mining district failed to take reasonable precautions, with resulting deaths in a village and loss of property. The Court placed special cmphasis on the adoption of regulations to mitigate the potential risk to human life from the activity involved. ${ }^{94}$ Regulations must govern the licensing, setting up, operation, security, supervision, and monitoring of the activity and must make it compulsory for all those concerned to take practical measures to ensure the effective protection of citizens whose lives might be endangered by the inherent risks. ${ }^{95}$ The choice of particular practical measures is in principle a matter within the state's margin of appreciation and the Court will seek to avoid placing an impossible or disproportionate burden on authorities, ${ }^{96}$ but the unjustified failure to act regarding foreseeable mortal risks will constitute a violation of Article 2 if deaths result due to the inaction.

The margin of appreciation opens wider in the sphere of emergency relief during and after natural disasters, 'which are as such beyond human control', than in regulating dangerous activities of a man-made nature. This deferential 
standard determined the outcome of the applicants' claim for breaches of the right to peaceful enjoyment of their possessions. The Court held that the state must only do what is reasonable in the circumstances to protect property, ${ }^{97}$ but it has a greater obligation to do everything within its power when the risk involves potential loss of life. The origin of the threat and the extent to which one or another risk is susceptible to mitigation are factors to be evaluated in determining the scope of the state's positive obligations. ${ }^{98}$ In this case, the authorities had been warned about the risks of devastating mudslides and had failed to provide resources for strengthening the local dams, known to be in a state of disrepair. No alternative land-planning policies were implemented or monitoring stations set up. The government provided no explanation. The Court noted that the public's procedural right of information can only be enjoyed if the government obtains the relevant information, which in this case was indispensable for ensuring the residents' safety. The authoritics' failure to ensure the functioning of an carly warning system thus was also unjustified.

Assessing risk is an important issue in litigating substantive environmental rights. Some human rights procedures limit standing to 'victims' of violations and there must be a sufficient threat for the applicants or petitioners to qualify as a victim. ${ }^{99}$ The precautionary principle has begun to play a role in bringing more risks within the ambit of human rights litigation. The case of Tuskin :" Titkey ${ }^{100}$ was one based on risk, stemming from the use of cyanide in gold extraction. The Court referred to the various reports that had been done on site which highlighted the risks. Domestic judicial findings also demonstrated the threat to the environment and lives of the neighbouring population. The Cour found Article 8 to be applicable "where the dangerous effects of an activity to which the individuals are likely to be exposed have been determined as part of an environmental impact assessment procedure in such a way as to establish a sufficiently close link with private and family life for purposes of Article 8 of the Convention. ${ }^{101}$ The Court held that this broad reading ivas necessary to ensure the effectiveness of Article 8.

Lack of judicial expertise and problems of evidence, especially causality, are frequently invoked as hurdles to giving substantive content to environmental rights. At the international level, they have not proved to be high hurdles thus far, because in most of the cases domestic fact-finding had already revealed the risks entailed or the harm. This was the case in Oneryildiz, ${ }^{102}$ Taskin $^{103}$ and Fadayeva. ${ }^{104}$ In the last-mentioned case, a government decree had recited statistics on the increases in respiratory and blood diseases linked to air pollution, as well as the increased number of deaths from cancer. ${ }^{105}$ The government had also determined by legislation the safe levels of various polluting substances, many of which were exceeded in the security zone where the applicant lived. The mayor of the city said the steel plant was responsible for more than 95 per cent of industrial emissions into the 
town's air, ${ }^{106}$ while a state Report on the Environment indicated that the plant in question was the largest contributor to air pollution of all metallurgical plants in Russia. The two statements substantially reduced questions about causality. ${ }^{107}$ In the end both parties agreed that the applicant's place of residence was affected by industrial pollution caused by the steel plant, but they disagreed over the degree and effects of the pollution. The government claimed that the disturbance caused by the pollution was not so severe as to raise an issue under Article 8. The applicant and the European Court disagreed, the latter explaining:

The assessment of that minimum is relative and depends on all the circumstances of the case, such as the intensity and duration of the nuisance, and its physical or mental effects. The general context of the environment should also be taken into account. There would be no arguable claim under Article 8 if the detriment complained of was negligible in comparison to the environmental hazards inherent to life in every modern city. ${ }^{108}$

Causality remained an issue on the applicant's health claims. Her medical records indicated problems, but did not attribute them to any specific causes. The doctors stated, however, that her problems would be exacerbated by working in conditions of vibration, toxic pollution and an unfavorable climate. ${ }^{109}$ The applicant also submitted an expert report ${ }^{110}$ which linked the plant specifically to increased adverse health conditions of persons residing nearby. The Court found that the medical evidence did not establish a causal link between the pollution at her residence and her illnesses, but accepted that the evidence, including submissions by the government, was clear about the unsafe excessive pollution around her home. The Court also made reference to the expert report and the findings of the domestic courts. The Court noted that Russian legislation defined the maximum permissible concentrations as 'safe concentrations of toxic elements'. 11 Therefore, exceeding these limits produced a presumption of unsafe conditions potentially harmful to the health and wellbeing of those exposed to it. This presumption, together with the evidence submitted, led the Court to conclude that the applicant's health deteriorated as a result of her prolonged exposure to the industrial emissions from the steel plant. Alternatively, even if that harm could not be quantified, the pollution 'inevitably made the applicant more vulnerable to various illnesses' and affected her quality of life at home. ${ }^{112}$ Therefore Article 8 applied.

The Court's analysis raises the question of what evidence would be sufficient to raise the presumption the Court creates in the Fadayeva case. It should not be limited to legislative findings, because as Zander $v$. Sweden ${ }^{113}$ indicates, safe levels may be changed to accommodate economic interests without necessarily being based on sound science. The World Health Organization (WHO) and other scientific bodies have determined through epidemiological 
Studies what constitutes safe levels of concentration of toxic, carcinogenic, mutagenic and other hazardous substances. ${ }^{114}$ Reliable evidence of such studies can and should be introduced to demonstrate presumed harm when such levels are excecded, even if local legislation permits higher concentrations. A petition to the Inter-American Commission, recently declared admissible, relies on such WHO standards to assert that the average sulphur dioxide levels from a metallurgical complex are detrimental to the lives and health of the nearby community in Peru. 115

The European Court's standard of proof is high ${ }^{116}$ but flexible and takes into account the fact that governments often are the sole repository of relevant evidence. Indeed, in the case of Fägerskiöld 1: Sweden ${ }^{117}$ the Court cited the World Health Organization guidelines 118 on noise pollution, in rejecting the admissibility of an application concerning wind turbines constructed and operating near the applicants' property. The Court noted that the guidelines are set at the level of the lowest adverse health effect associated with noise exposure. The Court also referred to even lower maximum levels adopted by most European countries. Applying these standards to the noise level tests submitted in the case, the Court found that the levels of noise did not exceed the WHO guidelines and were minimally above the recommended maximum level in Sweden. Therefore the environinental nuisance could not be found to reach the level of constituting severe environmental pollution. The Court also rejected the applicants' claims that their property rights were violated because the wind turbines decreased the value of their property. Assuming that there was an interference with property rights, the Court found that it was justified on several grounds, one of them being that the operation of the wind turbines was in the general interest as it is an environmentally friendly source of encrgy which contributes to the sustainable development of matural resoures. The Court considered whether these beneficial environmental conseyuenees were sufficient to outweigh the negative impact on the applicants. The Court reiterated its findings that the negative consequenees were not severe, while the availability of renewable energy is beneficial for both the environment and society. Moreover the government had taken measures to mitigate the negative impacts on the applicants. In sum, the alleged interference was proportionate to the aims pursued and no violation of property rights occurred.

In the Western Hemisphere, the Inter-American Commission has also devoted attention to environmental quality as it affects human rights. In many cases, litigants have sought protections for indigenous peoples' lands and resources threatened by environmental harm. In the case of Yomemami $v$ : Brazil ${ }^{119}$ the Inter-American Commission found that the government hald violated the Yanomani rights to life, liberty and personal security guarantecel by Article I of the American Declaration on the Rights and Dutics of Man, ${ }^{20}$ as well as the right of residence and movement (Article VIII) and the right to 
the preservation of health and well-being (Article XI) ${ }^{121}$ because the government failed to implement measures of 'prior and adequate protection for the safety and health of the Yanomami Indians'. ${ }^{22}$

The Yanomami case did not go into detail about the conduct required of a government or the standard of care the Commission would expect. Other cases and country studies ${ }^{123}$ have helped to clarify some issues in this respect, specifying that governments must enact appropriate laws and regulations, and then fully enforce them. In a country report on Ecuador, the Commission referred generally to the obligation of the state to respect and ensure the rights of those within its territory and the responsibility of the government to implement the measures necessary to remedy existing pollution and to prevent future contamination which would threaten the lives and health of its people, including through addressing risks associated with hazardous development activities, such as mining. ${ }^{124}$ Governments must regulate industrial and other activities that potentially could result in environmental conditions so detrimental that they create risks to health or life. ${ }^{125}$ Furthermore, the government must enforce the laws that it enacts as well as any constitutional guarantee of a particular quality of environment. ${ }^{126}$ The Commission was clear: "Where the right to life, to health and to live in a healthy environment is already protected by law, the Convention requires that the law be effectively applied and enforced.' 127

The state must also comply with and enforce the international agreements to which it is a signatory, whether these are human rights instruments or ones related to environmental protection. In the Ecuador report, the Commission noted that the state is party to or has supported a number of instruments "which recognize the critical connection between the sustenance of human life and the environment', 128 including: the Additional Protocol to the American Convention in the Area of Economic, Social and Cultural Rights, ${ }^{129}$ the International Covenant on Civil and Political Rights (ICCPR) ${ }^{130}$ and the International Covenant on Economic, Social and Cultural Rights (ICESCR), ${ }^{131}$ the Stockholm Declaration, ${ }^{132}$ the Treaty for Amazonian Cooperation, ${ }^{133}$ the Amazon Declaration, ${ }^{134}$ the World Charter for Nature, ${ }^{135}$ the Convention on Nature Protection and Wildlife Preservation in the Western Hemisphere, ${ }^{136}$ the Rio Declaration on Environment and Development, ${ }^{137}$ and the Convention on Biological Diversity. ${ }^{138}$ Through the standard-setting and enforcement process, the state must 'take the measures necessary to ensure that the acts of its agents ... conform to its domestic and inter-American legal obligations'. 139

States thus are not exempt from human rights and environmental obligations in their development projects: 'the absence of regulation, inappropriate regulation, or a lack of supervision in the application of extant norms may create serious problems with respect to the environment which translate into 
violations of human rights protected by the American Convention'. ${ }^{1+0}$ In the case of the Saramaka People v. Suriname, ${ }^{1+1}$ the Inter-American Court set forth three safeguards it deemed essential to ensure that development is consistent with human rights and environmental protection: (1) the state must ensure the effective participation of the members of the Saramaka people, in conformity with their customs and traditions, regarding any development, investment, exploration or extraction plan within Saramaka territory; (2) the state must guarantec that the Saramakas will receive a reasonable benefit from any such plan within their territory; and (3) the state must ensure that no concession will be issued within Saramaka territory unless and until independent and technically capable entities, with the state's supervision, perform a prior environmental and social impact assessment. ${ }^{1+2}$ It is notable that these requirements parallel the Bonn Guidelines on Access and Equitable BenefitSharing, ${ }^{143}$ adopted pursuant to the Convention on Biological Diversity, although the Court does not cite them, referring instead to views of the UN Human Rights Committee, ${ }^{144}$ ILO Convention No. 169, ${ }^{145}$ World Bank policies, ${ }^{146}$ and the 2007 UN Declaration on the Rights of Indigenous Peoples. ${ }^{147}$ The Court viewed benefit-sharing as inherent to the right of compensation recognized under Article 21(2) of the Inter-American Convention. ${ }^{148}$

\subsection{CONCLUSION: PROSPECTS AND PROBLEMS}

The advantages of rights-based approaches to environmental protection are several. First, because human rights are maximum claims on seciety, elevating a clean environment to a right raises it above a mere policy choice. Rights are inherent attributes that must be respected in any well-ordered socicty. The moral weight attached to a rights label excreises an important compliance pull on members of socicty.

Second, all legal systems establish a hicrarchy of norms. Constitutional or human rights guarantees usually are at the apex and 'trump' conflicting norms of lower value. Thus, to include respect for the environment as a constitutional right, or international human right, should ensure that it will be given precedence over other legal norms that are not rights-based. The Montana Supreme Court indicated some of the implications in the case Cape-France Enterprise's v. The Estate of Peed, describing the right to a clean and healthful environment as 'a fundamental right that may be infringed only by demonstrating a compelling state interest ...' one that is, "at a minimum, some interest "of the highest order and ... not otherwise served," or "the gravest abuse endangering [a] paramount [government] interest [ ]"149 Thus, environmental protection is not an ordinary policy choice and the burden of proof will be on the government to demonstrate a compelling reason for permitting the environment to 
deterioratc. This is important given the short-term costs that may make it unpopular politically to adopt and implement measures of environmental protection. A right to environmental quality can act as the brake or limitation on domestic political processes that otherwise might take a short-term view and permit activities that are significantly harmful to the environment and the people in it.

Third, the emphasis on procedural rights of information, participation, and access to justice encourages an integration of democratic values and promotion of the rule of law in broad-based structures of governance. Thus, ensuring these rights is not only a means to produce decisions favorable to environmental protection, but can reinforce respect for human rights, the rule of law and democratic values more generally. Experience suggests that repressive regimes also tend to ignore environmental conditions, that is, 'governments that show a disregard for their citizens' basic rights often protect the environment poorly as wcll' (Osofsky, 2005, p. 88). Citizen efforts to counter environmental harm tend to promote democratic governance as well as enhance compliance with environmental norms, something seen in particular over the past decade in Central and Eastern Europe.

This link should not be surprising: the process by which rules emerge, how proposed rules become norms and norms become law, is highly important to the legitimacy of the law and legitimacy in turn affects compliance. To a large extent, legitimacy is a matter of participation: the governed must have and perceive that they have a voice in governance through representation, deliberation or some other form of action.

Fourth, as already mentioned a rights-based approach enhances accountability by allowing utilization of international petition procedures to bring international pressure to bear when governments lack the will to prevent or halt environmental harm that threatens human health and well-being. In many instances, petitioners have been afforded redress and governments have taken measures to remedy the violation. Sometimes the problem is the result of a combination of governmental lack of capacity and lack of political will. Pollution may be caused by powerful enterprises whose business and investment are important to the state or the state may have inadequate monitoring systems to cnsure air or water quality. In these instances, petition procedures can help to identify problems and encourage their resolution, including by the provision of technical assistance. States may even welcome complaints if the results give them leverage in the domestic political arena to overcome opposition to needed measures. The availability of individual complaints procedures has given rise to extensive jurisprudence from which the specific obligations of states to protect and preserve the environment are detailed.

Turning to the problems, there are limits to what can be achieved through a rights-based approach. First, relying on existing human rights guarantees is 
anthropocentric, because environmental harm must affect human well-being before human rights guarantees can be invoked. Unless there is a specific right to a healthy or ecologically-balanced environment, international human rights procedures cannot be used on behalf of the environment or to prevent threats to other species or to ecological processes.

A second limitation to a rights-based approach to environmental protection is found in the limited mandates of human rights bodies in respect to remedies. The European Court can award monetary damages, but has little power to order injunctive relief or mandate specific action. Thus, rights may be vindicated with money for the applicants to move away from the environmental harm, but it is not clear that the environmental conditions themselves are improved in the short term. Fadayeva v. Russia ${ }^{150}$ is a case in point; she was awarded compensation, but the industrial facility, the steel mill, remained in operation as before. Yet, the Committee of Ministers (COM) does not close a case until there is compliance with the judgment, including general measures to ensure that the violation is not repeated. Subsequently, the COM invited the Russian authorities to hold consultations with the Council of Europe (COE) and experts on the general measures to be adopted to ensure that there is no repetition of the violation. It also requested the Russian authorities to draft an environmental code to be reviewed by the COE for compliance with regional standards.

A further limitation is that the decisions of the Inter-American Commission, the African Commission, and the UN bodies are recommendations that lack the binding force of judgments of the regional courts. While good faith cooperation with international bodies given monitoring power and the authority to hear complaints suggests that states should comply, they may take the view that recommendations need not be strictly followed.

Third, and less commonly, some states envisage rights as restraints on governmental power, with duties of governmental abstention, and do not accept human rights obligations that require affirmative managenent of resources and regulations to ensure that private conduct - which is responsible for the large majority of environmental harm - is properly controlled. But constitutional and human rights law now widely accepts affirmative state obligations to protect individuals against private as well as public violations of rights. It is important because the major difference between constitutional provisions that are based on traditional doctrines of public trust and those that enshrine environmental rights seems to be the extent to which private-source environmental harm is addressed. Including the right to environment in the constitution places it on an equal footing with rights to property and allows for a balancing of community and individual interests, more than does public interest doctrine.

A fourth limitation is inherent in the traditional scope of human rights law: 
a right to an environment of a certain quality is complicated by both temporal and geographic elements absent from other human rights protections. Environmental degradation harms not only those currently living, but also future generations of humanity as well. Can those not born be said to have rights and if so, who represents such future generations and how should courts protect their interests?

The most politically-charged aspect of a right to environment may be the potentially vast expansion of the territorial scope of state obligations. Presently, human rights instruments require each state to respect and ensure guaranteed rights to all individuals within its territory and subject to its jurisdiction. This geographic limitation reflects the reality that a state normally will have the power to protect or the possibility to violate human rights only of those within its territory and jurisdiction. Nature recognizes no political boundaries, however. A state polluting its coastal waters or the atmosphere may cause significant harm to individuals thousands of miles away. States that permit or encourage GHG emissions or depletion of the tropical rain forest can contribute to global warming that threatens the entire biosphere.

Ultimately, the definition of a right to environment will have to include substantive environmental standards to restrict harmful air pollution and other types of emissions. Although establishing quality standards requires extensive international regulation of environmental sectors based upon impact studies, such regulation is by no means impossible. Adoption of quality standards demands extensive research and debate involving public participation, but substantive minima are a necessary complement to the procedural rights leading to informed consent. Otherwise, a human rights approach to environmental protection would be ineffective in preventing serious environmental harm.

Establishing the content of a right through reference to independent and variable standards is often used in human rights, especially with regard to economic entitlements, and need not be a barrier to recognition of the right to a specific environmental quality. Rights to an adequate standard of living and to social security are sometimes defined in international accords such as the European Social Charter ${ }^{151}$ or Conventions and Recommendations of the International Labor Organization. States implement these often flexible obligations according to changing economic indicators, needs, and resources. The human rights treaties provide a 'framework' containing the basic guarantees on which international, national and local lavs and policies are elaborated.

A similar approach can be utilized to give meaning to a right to environment. Both the threats to humanity and the resulting necessary measures are subject to constant change based on advances in scientific knowledge and conditions of the environment. Thus, it is impossible for a human rights instrument to specify precisely what measures should be taken, that is, the products which should not be used or the chemical composition of air which must be 
maintained. These technical requirements can be negotiated and regulated through international environmental norms and standards, giving content to the right to environment by reference to independent environmental findings and regulations capable of rapid amendment. The variability of implementation demands imposed by the right to environment in response to different threats over time and place does not undermine the concept of the right, but merely takes into consideration its dynamic character.

So we have four approaches. There are challenges with each that require research and legal action from lawsuits to new instruments. The litigation will not always, or perhaps even often, result in immediate success, but is useful and perhaps even indispensable. The December 2005 lnuit petition to the Inter-American Commission on Human Rights ${ }^{152}$ led to the first hearing on human rights and climate change and the possible future appointment of a special rapporteur on human rights and the environment. Beyond litigation, there is a need for consideration of new problems and potentially new legal instruments articulating new rights.

Can there be a state without a territory? Already, in Kiribati people ask whether they will still have their citizenship if they have no territory - will they still have an exclusive economic zone if there is no land? Will they have a right to access other territory? How does the Responsibility to Protect apply in the environmental context? We should begin to consider the need to elaborate a legal instrument on population movements and perhaps on ecological intervention in cases of natural disasters where the government lacks resources to aid its own people, but rejects outside help.

In conclusion, human rights and environmental protection both ultimately seck to achieve the highest quality of sustainable life for humanity within the global ecosystem. Potentially conflicting differences of emphasis still exist, because the essential concern of human rights law is to protect individuals and groups within a given society, while the purpose of environmental law is to sustain all life and ecological processes by balancing the needs and capacitics of present generations with those of the future. Nonetheless, these two fundamental objectives of society are as interdependent as are the economies and communications networks of the world today. They must be integrated and addressed in a holistic manner that is sustainable and just, using all the legal techniques of the past and present as they may be modified to protect the future.

\section{NOTES}

1. 'World Bank Finds That Adjustment Places More in Step Poverty'. New York Times, 27 August 20)8, p.A7.

2. Ibid. 
3. It is estimated, for example, that the deforestation and consequent immigration of people into the Brazilian interior increased malaria prevalence in the region by 500\%: Smith, A.T.P. (2002), The Wealth of Nations (MIT Press).

4. See the statement of the Chair of the IPCC at the time of the launch of the second part of the IPCC's Fourth Assessment Report in 2007 as reported in http://environment.about.com' od/globalwarming/a/ipcc_report_two.htm (accessed 12 February 2012).

5. Brief of Amici Curiae Alaska Inter-Tribal Council et al. in Support of Petitioners, Mass. v. EPA, 127 S.Ct. 1438 (No. 05-1120).

6. The World Developmem Report 2000/200I of the World Bank defined poverty as 'the pronounced deprivation of well being.', http://siteresources.worldbank.org/ INTPOVERTY/Resources/WDR/English-Full-Text-Report/chl.pdf (accessed 2 February 2012), p. 15.

7. Ibid., p. 17, box 1.1 .

8. The eight goals are: eradicate extreme poverty and hunger; achieve universal primary education; promote gender equality and empower women; reduce child mortality; improve maternal health; combat HIV/AIDS, malaria and other diseases; ensure environmental sustainability; develop a global partnership for development. See http://www.un.org/ millenniumgoals/ (accessed 2 February 2012).

9. The Henry Eubank, 11 F. Cas. 1166, 1170 (D. Mass. 1833 (No. 6376); see also The Blackwall, 77 U.S. (10 Wall.) 1, 14, 2002 AMC 1808, 1815 (1869).

10. Convention (No. IV) Respecting the Laws and Customs of War on Land, with annex of Regulations (The Hague, Oct. 18, 1907), 36 Stat. 2277, T.S. No. 539, Preamble (emphasis adued).

11. Thus, for example, in the case of Diversion of the Waters of the Meuse, the PCIJ held that it was inequitable for the applicant state to complain of a wrongful act which the applicant itself had committed in the past. (1937) PCIJ: Ser. A/B 70, p. 25.

12. For other meanings see Schachter, O. (1991) International Law in Theory and Practice (Nijhoff Publishers), pp.55-56.

13. Universal Declaration of Human Rights, http:/www.un.org/en/documents/udhr/ index.shtml (accessed 2 February 2012), Preamble.

14. See Petersmann, E-U. Theories of Justice, Human Rights, and the Constitution of International Markets, (2003) Loy. L.A.L. Rev. 37, 407 at p. 412: "[C]ontrary to the suggestion by John Rawls to base international justice on equal freedoms of peoples, human rights offer a more appropriate constitutional basis for national as well as international justice.'

15. Federal Actions to Address Environmental Justice in Minority Populations and LowIncome Populations, Exec. Order No. 12898, 3 C.F.R. sec. 859 (1994), reprinted in 31 U.S.C.A. sec. 4321 at $7629-32$ (1994).

16. See for instance Article 2, 1997 UN Convention on the Law of Non-Navigational Uses of International Watercourses, http://untreaty.un.org/ilc/texts/instruments/english/conventions/ 8_3_1997.pulf (accessed 2 February 2012).

17. Case Concerning the Gabcikovo-Nagymaros Project (Hungary/Slovakia), Judgment of 25 September 1997, [1997] I.C.J. 7. See http://www.icj-cij.org/docket/files/92/7375.pdf (accessed 2 February, 2011).

18. Fisheries Jurisdiction Cases (United Kingdom v. Iceland; Federal Republic of Germany v. Iceland), Judgments of 25 July 1974, [1974] I.C.J. 3 and [1974] I.C.J. 175. See http://www.icj-cij.org/docket/index.php?pl=3\&p2=3\&k=f9\&case = 56\&code=bi\&p3= 4\&PHPSESSID=757ee871185687f 4805 ea9f22cef75f6 (accessed 2 February 2012)

19. Above, note 16 , Art. 5 .

20. Ibid., Art. 10.

21. http://www unhchr,ch/tbs/doc.nsf/0/3d02758c707031d58025677f003b73b9 (accessed 2 February 2012).

22. http://ozone.unep.org/new_site/en/Treaties/treaty_text.php?treatyID=2 (accessed 12 February 2012).

23. http://unfecc.int/essential_background/convention/background/items/2853.php (accessed 2 February 2012).

24. http://www.cbd.int/convention/text/ (accessed 2 February 2012). 
25. Moreover, Scolt Barrett's work has indicated that agreements perceived to be fair are not only likely to induce greater participation but are more likely to be self-enforcing and thus successful over the long term. Barret, S. (2003), Envirommem and Statecraft: The Strategy' of Environmental Treat -Making (Oxford University Press).

26. Trail Smelser (U.S. v: Cam.) (1941) RIAA iii.1905 at 1965; Ann. Digest (1938-40) no. 104.

27. Above, note 5.

28. Georgia v. Tennessee Copper Company and Ducksown Sulphur. Copper and Iron Company. Lul., 206 U.S. 230 (1907). This case defined the nature of the suit as one brought by the state in its capacity as quasi-sovereign, a capacity that gives it an interest "independent of and behind the titles of its citizens, in all the earth and air within its domain*. The Supreme Coun found that " $i t$ is a fair and reasonable demand on the part of a sovereign that the air over its territory should not be polluted on a great scale by sulphurous acid gas, that the forests on its mountains, be they better or worse. and whatever domestic destruction they may have suffered, should not be further destroyed or threatened by the act of persons beyond its control, that the crops and orchards on its hills should not be endangered from the same source'.

29. See, for example, Illinois Cemeral Ruilroud Co. :. Illinois, 146 U.S. 387 (1892); City of Milwaukee v: Siase, 214 N.W. 820 (Wis. 1927). Fishing rights, free access to the shore, and navigation are traditional rights that are reaffirmed in several state constitutions as well as in jurisprudence. Sec, for example, Cal. Const. art. I sec. 25: R.I. Const. art. I sec. 17; Ala. Const. ant $1 \sec 24$.

30. Alaska's constitution, for example, guarantecs the latter: "Wherever oxcuming in their natural state, fish, wildlife, and waters are reserved to the people for common use. Ala. Const. art. VIII, \$3. Rhode Island's Constitutional anendment, added in 1986, also focuses on public rights of aecess and use, coupled with a legislative mandate:

The people shall continue to enjoy and frecly exercise all the rights of fishery, and the privileges of the shore. to which they have been heretofore entitled under the cluarer and usages of this state; and they shall be secure in their rights to the use and enjoyment of the natural resources of the state with due regard for the preservation of their values, and it shall be the duty of the general assembly to provide for the conservation of the air. land, water, plant, animal, mineral and other natural resources of the state, and to adopt all means necessary and proper by law to protect the natural enviromment of the people of the state by providing adequate resource planning for the control and regulation of the use of natural rescources of the state and for the preservation, regenteration and restoration of the natural environment of the state.

31. For various approaches to the reach of the public trust, sec: Reed, S.W. (1986), The Public Trust Doctrine: Is it Amphibious?' J. Env'll l. \& lisig. 1, 107, at pp. 107-08, 118; Wilkinson, C.F. (1980), "The P'ublic Trust Dexerine in Public Lausd Law", U.C. Datis l.. Rev. 14, 269. at p. 316; Rieser, A. (1991). "Ecological Prexervation as a Public Property Right: An Emerging Doctrine in Search of a Theory', Ilarv. I:nvtl. L. Rev. 15, 393, at pp. $398-99$.

32. Sax, J. (1970), "The Public Trust Dectrine in Natural Resource Iaw: I:ffective Judicial Intervention', Mich. L. Rev. 68, 471. See also Cohen. B. (1970). 'The Constitution, the Public Trust Doctrine, and the Environment'. Uhah l.. Ra't. 388.

33. See, for example, Wade v. Kromer, 459 N.E.2J 1025, 1027 (III. App. Ct. 1984).

34. Haw. Const. an. XI, \&1.

35. See, for example, Montana Envirommental Information Center vi Department of Environmental Quality, 296 Mont. 207, 988 P'. 2d 1236 (1990).

36. Kury, F.L., "The Pennsylvania Environmental P'rotection Amendment". B. B. Ass' $N$ Q. Apr. 1987, at 85, 87, quoted in Kirsch, M.T. (1997). 'Upholding the Public Trust in State Constitutions', 46, Duke LJ. 116)-1210, at 1170 .

37. The vote was more than $3-1$ in favor of the amendment, with close to 2 million voters. Sec Kury, F.L. (1980), "The Environmental Amendment to the lennsylvania Constitution: 
Twenty Years Later and Largely Untested', vill. Envtl. L.J. 1, 123, 123-24 (1990) in Kirsch, op cit, at note 3.

38. Kirsch, in fact, argues that all of the successfully invoked provisions rely upon public trust doctrine, asserting that ' $[e]$ ach of the successful provisions invokes some combination of the concepts undergirding the public trust doctrine: conservation, public access, and tristecship'. Kirsch, op cit, at 1173. Provisions that refer to 'trust,' include Haw. Const. art. $\mathrm{XI}$; Pa. Const. art. 1, \$ 27; Va. Const. art. XI, § 3. For provisions outlining public trust principles, see Ala. Const. art. VIII; Cal. Const. art. X, § 2; Fla. Const. art. II, § 7; La. Const. art. IX; Mass. Const. \$ 179; Mich. Const. art. IV, § 52; Mont. Const. art. IX, § 1; N.M. Const. art. XX, § 21; N.Y. Const. ant. XIV; N.C. Const. art. XIV, § 5; R.I. Const. art. 1, § 17; Tex. Const. art. XVI, \&59.

39. The International Covenant on Economic, Social and Cultural Rights (IESCR) (16 December 1966), http://wwww2.ohchr.org/english/law/cescr.htm (accessed 2 February 2012) speaks primarily to the working environment, guaranteeing the right to safe and healthy working conditions (art. $7 \mathrm{~b}$ ) and the right of children and young persons to be free from work harmful to their health (art. 10 para. 3). The right to health (IESCR, art.12), however, goes further and expressly calls on states parties to take steps for 'the improvement of all aspects of environmental and industrial hygiene' and 'the prevention, treatment and control of epidemic, endemic, occupational, and other diseases'.

40. The Convention on the Rights of the Child (New York, 20 November 1989), http://www2.ohchr.org/english/law/crc.htm (accessed 2 February 2012) refers to aspects of environmental protection in respect to the child's right to health. Article 24 provides that states parties shall take appropriate measures to combat disease and malnutrition 'through the provision of adequate nutritious foods and clean drinking water, taking into consideration the dangers and risks of environmental pollution'. (Art. 24(2)(c)). States parties also are to provide information and education on hygiene and environmental sanitation to all segments of society. (Ar. 24(2)(e)), ILO Convention No. 169 concerning Indigenous and Tribal Peoples in Independent Countries (Geneva, June 27 1989) see http://www.ilo.org/ ilolex/cgi-lex/convde.pl? Cl69 (accessed 2 February 2012) contains numerous references to the lands, resources, and environment of indigenous peoples (for example, Arts. 2, 6, 7, 15). The Convention requires states parties to take special measures to safeguard the environment of indigenous peoples (Art. 4). In particular, governments must provide for environmental impact studies of planned development activities and take measures, in coroperation wish the peoples concerned, to protect and preserve the environment of the territories they inhabit.

41. The most recent UN human rights text, the United Nations Declaration on the Rights of Indigenous Peoples, adopted by the General Assembly on 12 September 2007 see http://wwww.un.org/esa/socdev/unpfii/en/drip.html (accessed 2 February 2012) with only four dissenting votes (U.S., Canada, Australia and New Zealand) contains several provisions related to environmental rights. In addition to protection of indigenous lands (Arts. 10, 25-27) and resources (Arts. 23, 26) the declaration contains procedural rights of participation (Art. 18) and prior informed consent (Art. 19) as well as a specific article on the environment. Article 29 provides:

1. Indigenous peoples have the right to the conservation and protection of the environment and the productive capacity of their lands or territories and resources. States shall establish and implement assistance programmes for indigenous peoples for such conservation and protection, without discrimination.

2. States shall take effective measures to ensure that no storage or disposal of hazardous naterials shall take place in the lands or territories of indigenous peoples without their free, prior and informed consent.

3. States shall also take effective measures to ensure, as needed, that programmes for monitoring. maintaining and restoring the health of indigenous peoples, as developed and insplemented by the peoples affected by such materials, are duly implemented. 
42. The African Charter on Human and Peoples' Rights, (Banjul, 26 June 1981), see http://wwwl.umn.edu/humanns/instree/zl afchar.htm (accessed 2 Febnuary 2012). Aricle 24 provides that "All peoples shall have the right to a general satisfactory environment favorable to their development." The Additional Protocol to the American Convention on Human Rights in the area of Economic, Social and Cultural Rights, http://www.oas.org/juridico/english/treaties/a-52.html (accessed 2 February 2012), also contains a right to environment, but did not add it to those rights subject to the individual complaint procedure. Article 11, entitled: 'Right to a healthy environment' proclains:

1. Everyone shall have the right to live in a healthy environment and to have access to basic public services.

2. The States Parties shall promote the protection. preservation and improvement of the environment.

The 2004 Revised Arab Charter on Human Rights, see http:/wwwl.umn.edu/humanrts/ instree/loas2005.html (accessed 2 February 2012) also guarantces a right to a safe and healthy environment. Its Article 38 specifies:

Every person has the right to an adequate standard of living for himself and his family. that ensures their well-being and a decent life, including $f(x)$, clothing, housing. services and the right to a healthy environment. The States partics shall take the necessary measures commensurate with their resourees to guarantec these rights.

43. See, for example, the Convention on Access to Information. Public Participation and Access to Justice in Environnental Matters (Aarhus, June 25, 1998), http://www. unce.org/cnv/pp/documents/cep-13e.pdf (accessed 2 l"cbruary 2012); Prolocol to the 1979) Convention on Long-Range Transboundary Air Pollution Concening the Control of Emissions of Volatile Organic Compounds or Their Transboundary Filuxes (Geneva, 18 November 1991). An. 2(3)(a)(4), http://www.unece.org/env/lnap/voln_hl.htm (alecessed 2 February 2012): Convention on the Protection and Utilization of International Watercourses and International L,akes (Helsinki, 17 March 1002), Art. 16, see http://www.unece.org/env/water/ (accessed 2 lebnary 20) 2; the regional seas agreements; Convention on Civil Responsibility for Damage Resulting from Activities Dangerous (o the Environment (1.ugano, 21 June 1993. Arts. 13-16, hitp://consentions.coceint/treaty/col treaties/html/150.htm (aecessed 2 lebrary 2012); and United Nalions lranework Convention on Climate Change (Rio de Janciro, 9 May 1902), above, note 23, Art. 6. Non. binding texts include the European Charter on the Environment and llealth, adopted 8 December 1989, http://whylibdoc.who.int/euro/.1993/1CP.RUD_113.pdf (accessed 2 February 2012); Ministerial Declaration on Environmentally Sound and Sustainable Development in Asia and the Pacific (Bangkok, 16 October $19(x)$ ), A/CONF:151/PC/38 (Para. 27 affirms the right of individuals and nongovernmental organizations to be informed of environnental problems relevant to them, to have necessary access to information, and to participate in the formulation and implementation of decisions likely to affect their environment'.); Arab Declaration on Environment and Development and Future Perspectives (Cairo, September 1991), A/46/632, cited in U.N. Dic. : $/ C N .4 / S u b .2 / 1992 / 7$, 20 (affirming the right to information about environmental issues).

44. http://www.unep.org/Documents. Multilingual/Default.asp?documentid $=78 \&$ articleid $=1163$ (accessed 2 February 2012). For relevant instruments adopted after the Rio Declaration see for example, Protocol on Water and Health to the 1992 Convention on the Protection and Use of Transboundary Watercourses and International Lakes (london. 17 June 1999), hitp://www.unece.org/env/document $s / 20(\%) / w a t / m p$. wat.20(K).1.e.pdf (accessed 2 February 2012); the United Nations Convention to Combat Desertification in Those Countries Experiences Serious Drought and/or Desertification (14 Octoler 1994), http://www.unccd.int/convention/text/convention php?annex $N o=0$ (accosed 2 liebruary 
2012) which places human beings at the center of concern to combat desertification (Pmbl) and requires states parties to ensure that all decisions to combat desertification or to mitigate the effects of drought are taken with the participation of populations and local communities. (Art. 3). The Convention places an emphasis throughout on information and participation of local communities. The Rotterdam Convention on the Prior Informed Consent Procedure for Certain Hazardous Chemicals and Pesticides in International Trade (10 September 1998), EMuT, 998:26, http://www.pic.int/home.php?type=s\&id=77 (accessed 2 February 2012), Art $15(2)$, requires each state party to ensure, to the extent practicable that the public has appropriate access to information on chemical handling and accident management and on alternatives that are safer for human health or the environment than the chemicals listed in Annex IIl to the Convention. The Cartagena Protocol on Biosafety to the Convention on Biological Diversity (Montreal, 29 January 2000), 39 I.L.M.1027, http:/bch.cbd.int/protocol/text/ (accessed 2 February 2012), Art. 23 concerns public awareness and participation, requiring the Parties to facilitate awareness, education and participation conceming the safe transfer, handling and use of living modified organisms in relation to the conservation and sustainable use of biological diversity, taking into account risks to human health. Access to information on imported LMOs should be ensured and the public consulted in the decision-making process regarding such organisms, with the results of such decisions made available to the public. Further, each Party shall endeavour to inform its public about the means of public access to the Biosafety Clearing-House created by the Convention.

45. Resolution 2001/35, Adverse effects of the illicit movement and dumping of toxic and dangerous products and wastes on the enjoyment of human rights, E/CN.4/RES/2001/35.

46. All of the reported cases involved harm to persons as a result of the transboundary movement of hazardous materials, nearly always in violation of national and intemational environmental law. See the Report of the Special Rapporteur on the Adverse Effects of the Illicit Movement and Dumping of Toxic and Dangerous Products and Wastes on the Enjoyment of Human Rights, Addendum, Commission on Human Rights, E/CN.4/2001/55/Add.l (21 Dec. 2000), documenting inter alia damage to tissues from arsenic poisoning, risks to health from the dumping of heavy metals, illnesses from pesticide use at banana plantations, deaths from petrochemical dumping, and kidney failure in children due to contaminated pharmaceuticals. In its resolutions on this matter, the Comnission consistently recognized that such trade 'constitute[s] a serious threat to the human rights to life, good health and a sound environment for everyone'. See Commission on Human Rights, Resolutions 199/23 and 2000/72.

47. Resolution 20(0)1/25, The right to food, E/CN.4/RES/2001/25 of 20 April 2001. The Commission's Sub-Commission on Promotion and Protection of Human Rights also pressed the isste of the right to drinking water and sanitation, conducting a detailed study on the relationship between the enjoyment of economic, social and cultural rights and the promotion of the realization of the right to drinking water supply and sanitation. Resolution 2001/2. Promotion of the realization of the right to drinking water and sanitation, E/CN.4/Sub.2/RES/2001/2 of 10 August 2001.

48. The Commission also adopted several resolutions linking human rights, health and the environment, such as Res. 2005/60 (20 April 2005), entitled Human rights and the enviromment as part of sustainable development. The resolution cited relevant UN conferences from Stockholm to Johannesburg and the goals and targets of the United Nations Millennium Declaration.

49. See Resolution $2 / 23$ (28 March 2008) at http://www2.ohchr.org/english/issues/clinate change/docs/Resolution_7_23.pdf (accessed 2 February 2012).

50. Above, note 42 .

51. See Art. 1(7), Art. 2(2)(i), and Art. 14 for human rights provisions as well as Art. 1(9) with regard to the environment in the Charter of the Association of Southest Asian Nations, adopted 20 November 2007, www.asean.org (accessed 2 February 2012).

52. http://conventions, coe.int/treaty/Commun/QueVoulezVous.asp?NT $=005 \& \mathrm{CL}=\mathrm{ENG}$ (accessed 2 February 2012).

53. Christine Goodwin v. The United Kingdom [GC], App. No. 28957/95, judgment of 11 July 2002, 35 EHIRR 18 (2002), para. 74. 
54. Recall that the Vienna Convention on the Law of Treaties, http://untreaty.un.org/ilc/ texts/instruments/english/conventions/1_1_1969.pdf (accessed 2 February 2012), allows recourse to the drafting history (travaux presparatoires) as a subsidiary means of interpretation (Art. 32) only if the application of Art. 31 leaves the meaning absurd or ambiguous.

55. See Mangouras v. Spain, no. 12050/04, Decision of the Grand Chamber, 28 Sept. 2010.8 Jan. 2009, para. 86. See http://cmiskp.echr.coe.int/kp 197/viewv.asp?item=1\&portal= hbkm\&action=html\&highlight=mangouras $\% 201 \% 20$ spain\&sessionid=85911271 \& skin=hu doc-en (accessed 2 February 2021). Increased concern with the environment has also proved important in cases where states have taken measures l:o protect the environment and the actions are resisted on the grounds that they interfere with the right to property. In Fredin $v$. Sweden the applicant argued that nature protection was an inadequate reason to revoke a license to extract gravel on his property and therefore was a violation of Article I, Protocol 1. The Court found no violation, noting that the protection of the environment is an increasingly important consideration. Fredin v. Sweden, No. 12033/86, 13 EHRR. 784 (1991). The Court similarly found no violation of the same provision in Pine Valley Developments Lid v. Ireland, where permission to carry out construction in a green belt area was revoked on grounds of environmental protection. Pine Valley Devs. Lid. v Ireland. App. No. 12742/87, 14 EHRR. 319 (1992). The most difficult and contentious cases in this respect have concerned travellers or gypsies, whose lifestyle may bring them into contact with modem land use planning. The European Court has repeatedly refused to override local zoning restrictions, especially the creation of green belts, in order to ensure a permanent home for this minority group. See Buckley v. United Kingdom, 1996-IV Eur. Ct. H.R. 1271 (1996) and the four recent cases: Smith v. United Kingdom, App. No. 25154/94, 33 EHRR 712 (200I); Lee v. United Kingdom, App. No. 25289/94, 33 EHRR 677 (2001); Chapman v. United Kingdom, App. No. 27238/94, 33 EHRR 399 (2001); Beard v. United Kingdom, App. No. 24882/94, 33 EHRR (2001).

56. Mangouror v. Spain, op cit.

57. International Convention for the Prevention of Pollution from Ships, 2 November 1973 (MARPOL 73/78) and the Protocol thereto adopted 17 February 1978. See http://www.imo.org/about/conventions/listofonventions/pages/intermational-conventionfor-the-prevention-of-pollution-from-ships-(marpol).aspx (accessed 2 Fobruary, 2012).

58. The Court cited two European Community directives, Directive 2(K)4/35/CE of 21 April 2004 on environmental liability with regard to the prevention and remedying of environmental damage; and Directive 2005/35/EC of 7 Septenber 20(05 on ship-source pollution and on the introduction of penalties for infringements.

59. Lopez Ostra v. Spain, Eur. Ct. Hum. Rts [1994] Ser. A, No. 303C.

60. In L'owell \& Raynor v. United Kingdom, Eur. Ct. Hum. Rts [1990) Ser. $A$ No. 172, the European Court found that aircraft noise from Ileathrow Airport constituted a violation of Article 8, but was justified as 'necessary in a democratic society' for the economic wellbeing of the country and was acceptable under the principle of proportionality because it did not "create an unreasonable burden for the person concemed'. The latter text could be met by the state if the individual had 'the possibility of moving elsewhere without substantial difficulties and losses'.

61. Many of the European environmental cases invoking the protection of privacy and home life involve noise pollution. See Arrondelle v. United Kingdom, (1980)19 DR 186; (1982) 26 DR 5; Powell \& Raynor v. United Kingdom, 172 Eur.Ct. H.R. (1990); and Hattom and Others $v$. The United Kingdom (GC) 20(03, 37 EHRR 28, applying a 'fair balance' test and finding no violation due to aircraft noise from Heathrow Airport.

62. Fadayeva v. Russia, no. 55723/00, judgment of 9 June 2005, 2005/IV Eur. Ci.H.R. 255 (2005).

63. Oneryildiz v. Turkey, no. 48938/99, (GC), Reports 2004-VI (30 Nov.).

64. Convention on Civil Liability for Damage resulting from Activities Dangerous to the Environment, above n. 43.

65. Convention on Protection of the Environment through Criminal Law, Strasbourg. 4 Nov. 1998, E.T.S. No. 172. See http://conventions.coe.int/treaty/en/Treaties/ $/ 1 \mathrm{ml} / 172$.htm (accessed 2 Pebruary 2012). The Court noted that the Strasbourg Convention was not in 
force, but found it 'very much in keeping with the current trend towards harsher penalties for damage to the environment."

66. http://assembly.coe.int/Main.asp?link=/Documents/AdoptedText/ta75/ERES587.htm (visited 2 February 2012)

67. http://assembly.coe.int/Main.asp?link=/Documents/AdoptedText/ta96/ERES1087.htm (visited 2 February 2012).

68. http://assembly.coe.int/Documents/AdoptedText/ta93/EREC1225.HTM (visited 2 February 2012).

69. Taskun and Others v. Turkey, no. 49517/99, $\S \S 99$ and 119, 2004-X Eur. Ct. H.R. 145 (2005).

70. Aarhus Convention, above, note 43.

71. Parliamentary Assembly Recommendation 1614 (2003) of 27 June 2003. See http:// assembly.coe.int/Main.asp?link=/Documents/AdoptedText/ta03/EREC1614.htm (visited 2 February 2012). See also Okyay and Others v. Turkey, Okyay et autres c. Turquieland Others v. Turkey, no. $36220 / 97$ (Sect. 2) (bil.),CEDH/ECHR 2005-Vll.

72. See: Mareno Gomez v. Spain, no. 4143/02, 16 Nov. 2004, para. 55; Giacomelli v. Italy, no. 59909/60, 12 Oct. 2006, paras. 78-79; Surugiu v. Romania, no. 48995/99, 20 April 2004.

73. Velasquez Rodrigue: Case, 4 Inter-Am. Ct. H.R. (ser. C) at 155 (Judgment of July 29, 1988) (concerning disappearance of civilians perpetrated by the Honduran army); Godinez Cruz Case, 5 Inter-Am. Ct. H.R. (ser. C) at 152-53 (Judgment of 20 January 1989).

74. See, for example. Ashworth and Others v. the Unired Kingdom, App. No. 39561/98, 20 Jan. 2004; , Moreno Gomes v. Spain, 2004-X Eur. Ct. H.R. 327 (2005).

75. Okyay and Others v. Turkey, above, note 71 at 57.

76. Kyrtatos v. Grecece, no, 41666/98, 22 May 2003, 2003-V1.

77. Social and Economic Rights Action Cemer/Center for Economic and Social Rights v. Nigeria, Conim. 155/96, Case No. ACHPR/COMM/A044/1, 27 May 2002.

78. lbid., para. 53.

79. Giacomelli, above, note 72, para. 80 .

80. Falayeva 1. Russia, above note 62 at para. 104, citing Hatton, above, note 61, para. 122.

81. Ibid.

82. lbid., paras. 102-103.

83. Ibid., para. 105, citing Taskin and others b. Turkey, above, note 69.

84. In particular, the Court says it would be going too far to assert that the state or the polluting undertaking were under an obligation to provide the applicant with free housing. lbid.,para. 133. It is enough to say that the situation called for a special treatment of those living near the plant.

85. Complaint No. 30/2005 Marangopoulos Foumdation for Human Rights (MFHR) \&. Greece, http://wwww.coe.int/t/dghl/monitoring/socialcharter/complaints/CC30CaseDoc l_en.pdf (accessed 2 February 2012).

86. The Committee transmitted its decision on the merits to the Committee of Ministers and to the Parties on 6 December 2006. The Committee of Ministers adopted its resolution on the matter on 15 January 2008 . Sec https://wcd.coe.int/wed/ViewDoc.jsp?Ref=CM/Notes/99.1/ 4.2J\&Language=lanEnglish\& Ver=original\&Site=CM\& BackColorlnternet=DBDCF2\&Ba ckColorlntranet=FDC86+\& BackColorLogged=FDC864 (accessed 2 February 2012).

87. According to the Committee, ibid, '[t]he Greek National Action Plan for 2005-2007 (NAP') provides for greenhouse gas emissions for the whole country and all sectors combined to rise by no more than $39.2 \%$ until 2010 , whereas Greece was committed, in the framework of the Kyoto Protocol, to an increase in these gases of no more than $25 \%$ in 2010. When air quality measurements reveal that emission limit values have been exceeded, the penalties imposed are limited and have little dissuasive effect. Moreover, the initiatives taken by DEH (the public power corporation operating the Greek lignite nines) to adapt plant and mining equipment to the "best available techniques" have been slow.'

88. Guerra vi Italy, App. No: 14967/89, Reports 1998-1, no. 64.

89. Ahove, note 63, para, 71.

90. Ibid. para. 90.

91. Ibid. para. 101. 
92. Ibid.

93. Budayev' and Others v. Russia, App. No. (2008) ECHR 15339/02 \& Ors (20 March 2008).

94. Ibid, para. 132.

95. Ibid.

96. Ibid, para. 135.

97. Ibid, at para. 174. While the Court found that the measures taken by the state were negligent, it found the causal link was not well-established. The mudslide of 2000 being exceptionally strong, the Court said it was unclear whether a functioning warning system or proper maintenance of the defence infrastructure would have mitigated the damage.

98. Ibid, at para. 137.

99. See Bordes and Temeharo v. France, Comm. No. 645/1995, CCPR/C/57/D/645/1995, 30 July 1996. The risk of harm from nuclear radiation due to nuclear testing by France in the South Pacific deemed too remote for the victims to qualify as victims.

100. Taskin, above, note 69 .

101. Ibid., para. 113 [emphasis added].

102. Oneryildiz, above, note 63 .

103. Taskin, above, note 83 .

104. Fadayeva v. Russia, above note 62. See also Ledyayeva, Dobrokhotova, Zolotareva and Romashina v. Russia, nos. 53157/99,53247/99, 53695/00 and 56850/00, judgment of 26 October 2006, also involving the same steel plant built during the Soviet era.

105. Russia's Constitution, art. $\mathbf{4 2}$ guarantees as follows: 'Everyone has the right to a favorable environment, to reliable information about its state, and to compensation for damage caused to his health or property by ecological disease. 'The provision was not invoked in the case.

106. The Court noted that this made the case different from and more easily definable than other air pollution cases where multiple minor sources cumulate to produce the problem. Fadayeva, above, note 63, para. 91.

107. The Court noted that the parties produced official documents containing generalized information on industrial pollution, because basic data on air pollution are not publicly available. Ibid., para. 30 .

108. Ibid., para. 69.

109. Ibid., para. 45.

110. The court made it a point to recite the qualifications of the expert when discussing the report. See ibid., para. 46, n. 1.

111. Ibid., para. 87.

112. Ibid., para. 88.

113. In Zander v. Sweden. App. No. 14282/88, Eur. Ct. Hum. Rts [1993] Ser. A, No. 279B, where the applicants complained about contamination of their well water by cyanide from a neighboring dump site. The municipality initially fumished temporary water supplies, but later, adhering to the normal regulatory procedures, the town raised the permissible level of cyanide in the city water supply. The permit for the dump was later renewed and expanded, while the applicant's request for safe drinking water was denied.

114. The WHO has developed guidelines for safe and acceptable water quality and quantity. World Health Organization, 'Guidelines for Drinking Water Quality' (3d edn. 2(1)4). Sce http://www.who.int/water_sanitation_health/dwq/GDWQ2004web.pdf (visited 2 February 2012) Independent surveillance of water quality, quantity, accessibility, affordability and long term availability are part of the WHO framework.

115. Inter-American Commission on Human Rights, Report No. 76/09, Case 12.718, Community of La Oroya, Peru, admissibility decision of 5 August 2009 , OAS/Ser/L/V/II.135, doc. 23.

116. It has long demanded 'proof beyond reasonable doubt.' Fadayeva, above, note 62, para. 79 which can follow from the coexistence of sufficiently strong, clear and concordant inferences or of similar unrebutted presumptions of fact.

117. Fägerskiöld v. Sweden, no. 37664/04, (admissibility), 26 February 2008.

118. World Health Organization, 'Guidelines for Community Noise' (Geneva 1999), http://www, who.int/docstore/peh/noise/guidelines2.html (accessed 2 February 2012). 
119. Yanomami Case, Res. No. 12/85, Case 7615 (Brazil), in Annual Report of the IACHR 1984-1985, OEA/Ser.L/V/II.66, doc. 10, rev. 1 (1985), 24.

120. http://www.cidh.oas.org/Basicos/English/Basic2.American\%20Declaration.htm (accessed 2 February 2011).

121. Above, note 119 , at 33 .

122. Ibid., at 32.

123. Inter-Am.C.H.R., Report on the Situation of Human Rights in Ecuador, OEA/Ser.L/V/II.96, doc. 10 rev. 1 (1997), also at http:/www.cidh.oas.org/countryrep/ ecuador-eng/Index 7020-\%20Ecuador.htm (accessed 2 February 2012) (hereinafter Report on Ecuador); Inter-Am.C.H.R., Report on the Situation of Human Rights in Brazil, OEA/Ser.L/V/II.97. doc. 29, rev. 1 (1997); Inter-Am. C.H.R., Third Report on the Situation in Paraguay, OEA/Ser.L/V/II.110, Doc. 52, 9 March 2001.

124. Report on Ecuador, op cit, at 94.

125. Ibid., p. v.

126. In the Ecuador report, the Commission heard allegations that the Government had failed to ensure that oil exploitation activities were conducted in compliance with existing legal and policy requirements. The Commission's onsite delegation also heard that the Government of Ecuador had failed to enforce the inhabitants' constitutionally protected rights to life and to live in an environment free from contamination. The domestic law of Ecuador recognizes the relationship between the rights to life, physical security and integrity and the physical environment in which the individual lives. The first protection accorded under Article 19 of the Constitution of Ecuador, the section which establishes the rights of persons, is of the right to life and personal integrity. The second protection establishes 'the right to live in an environment free from contamination'. Accordingly, the Constitution invests the state with responsibility for ensuring the enjoyment of this right, and for establishing by law such restrictions on other rights and freedoms as are necessary to protect the environment. Thus, the Constitution establishes a hierarchy according to which protections which safeguard the right to a safe environment may have priority over other entitlements. Ibid., pp. 78-86.

127. Ibid.

128. Sce Chapter 8 of the Report at http://www.ciuh.oas.org/countryrep/ecuador-eng/ Chaper-8.htm (accessed 2 February 2012).

129. Above, note 42.

130. http://www2.ohehr.org/english/law/cepr.htm (accessed 2 February 2012).

131. Above, note 39.

132. http://www.unep.org/Documents.Multilingual/Default.asp? DocumentID=97\&ArticleID= 1503\&l=en (accessed 2 February 2012).

133. Treaty for Amazonian Cooperation, 17 I.L.M. 1045 (1978).

134. Amazon Declaration, 28 1.L.M. 1303 (1989).

135. World Charter for Nature, G.A. Res. 377, U.N. Doc. A/37/51 (1982).

136. Convention on Nature Protection and Wildlife Preservation in the Western Hemisphere, 161 U.N.T.S. 229 (1940).

137. Above, note 44.

138. Above, note 24.

139. Report on Ecuador, above, note 123, 89 at 92.

140. Ibid., at 89.

141. Case of the Saramaka People v. Suriname, Inter-Am. Ct. Hum. Rts, Ser. C No. 172 (28 Nov. 2007).

142. Ibid., at para. 129.

143. http://www.cbu.int/doc/publications/cbd-bonn-gdls-en.pdf (accessed 2 February 2012).

144. See ICCPR, General Comment No. 23, The Rights of Minorities (Art. 27), U.N. Doc. CCPR/C/21 Rev 1/Add.5. 4 August 1994 and Apirama Malkuika et al. v. New Zealand, U.N. doc CCPR/C/70/D/47/1993, 15 Novenber, 2000.

145. Above, note 40.

146. See World Bank, Revised Operational Policy and Bank Procedure on Indigenous Peoples, OP'/BP 4.10. 
147. Supra, note 41 .

148. http://www.cidh.oas.org/basicos/english/basic3.american\%20convention.htm (accessed 2 February 2012). Article 21(2) provides that [n]o one shall be deprived of his property except upon payment of just compensation, for reasons of public utility or social interest, and in the cases and according to the forms established by law.

149. Cape-France Enterprises v. The Estate of Peed, 305 Mont. 513, 29 P.3d 1011 (2001), citing Armstrong :. State, 1999 Mt. 261, 296 Mont. 361, 989 P. 2d 364, at fn. 6.

150. Above, note 62 .

151. http://www.coe.int/T/DGHL/Monitoring/SocialCharter/ (accessed 2 February 2012).

152. Above, note 5 .

\section{REFERENCES}

Akehurst, M., (1976) 'Equity and General Principles of Law', Int'l \& Comp. L.Q. 25, 801 .

Ballard, R. (1993) 'Race and Environmental Justice in the United States', Yale J. In'l L. 18,319 .

Bosselman, K. and B. Richardson (eds), (1999), Environmental Justice and Market Mechanisms: Key Challenges for Environmental Law and Policy (Kluwer Intermational).

Drumbl, M.A. (2002), 'Poverty, Wealth, and Obligation in International Environmental Law', Tulane L. Rev., 76, 843.

Franck, T. (1995), Fairness in International Law and Institutions (Clarendon Press). Humphrey, J.P. (1945), 'On the Foundations of International Law', AJIL 39, 231. Intergovernmental Panel on Climate Change (IPCC) (2001), Climate Change 2001: Impacts, Adaptation, and Vulnerability (A Report of Working Group II of the IPCC).

International Committee of the Red Cross (ICRC) (1999), Anmual Report.

Justinian Institutes, 2.1.1 (T. Sanders Trans. 1st Am. ed. 1876).

Office of the High Commissioner for Human Rights (OHCHR), Claiming the Millennium Development Goals: A Human Rights Approach (2008). Geneva, HR/PUB/08/3, sales no. E.08.XIV.6.

Osofsky, H.M. (2005), 'Learning from Environmental Justice: A New Model for International Environmental Rights', Stan. Envtl L.J., 24, 71.

Philimore, R. (1871), Cotnmentaries upon International Law: Vol. 1 (2nd cdn), (Butterworths).

Platt, A.E. (1996), Infecting Ourselves: How Environmental and Social Disruptions Trigger Disease, Worldwatch Paper 129 (World Watch Institute).

Rehbinder, E. (1999), 'States between Economic Deregulation and Environmental Responsibility' in K. Bosselmann and B. Richardson (eds), Environmental Justice and Market Mechanisms: Key Challenges for Environmental Law and Policy (Kluwer International).

Reitze, A.W. Jr. (1989), Environmental Policy - It is Time for a New Beginning,' 4 Columbia J. Envul L. 4, 111.

Schroeder, C.H. (2002), Lost in Translation: What Environmental Regulation Does that Tort Cannot Duplicate, Washburn L.J. 41, 583.

Silving, H. (1961), 'In re Eichmann: A Dilemma of Law and Morality,' AJJL 55, 307.

Sze, J. (2005) 'Race and Power: An Introduction to Environmental Justice Energy 
Activism', in N. Pellow and R.J. Brulle (eds), Power, Justice, and the Environment: A Critical Appraisal of the Environmental Justice Movement (MIT Press).

United Nations Development Programme (UNDP) (2007), Human Development Report.

World Bank (2002), Linking Poverty Reduction and Environmental Management: Policy Challenges and Opportunities (The World Bank). 